Crime and Punishment in the Middle Ages and Early Modern Age 


\section{Fundamentals of Medieval and Early Modern Culture}

Edited by

Albrecht Classen and Marilyn Sandidge

11

De Gruyter 


\title{
Crime and Punishment in the Middle Ages and Early Modern Age
}

\author{
Mental-Historical Investigations \\ of Basic Human Problems and Social Responses
}

Edited by

Albrecht Classen and Connie Scarborough

De Gruyter 
ISBN 978-3-11-029451-4

e-ISBN 978-3-11-029458-3

ISSN 1864-3396

\section{Library of Congress Cataloging-in-Publication Data}

A CIP catalog record for this book has been applied for at the Library of Congress.

\section{Bibliographic information published by the Deutsche Nationalbibliothek}

The Deutsche Nationalbibliothek lists this publication in the Deutsche Nationalbibliografie; detailed bibliographic data are available in the Internet at http://dnb.dnb.de.

(C) 2012 Walter de Gruyter GmbH, Berlin/Boston

Printing and binding: Hubert \& Co. GmbH \& Co. KG, Göttingen $\infty$ Printed on acid-free paper

Printed in Germany

www.degruyter.com 


\section{Table of Contents}

\section{Introduction}

Albrecht Classen and Connie Scarborough

Crime, Transgression, and Deviancy: Behaviors that Defines Us All . . . . . 1

\section{Chapter 1}

Bernard Ribémont

Le 'crime épique' et sa punition: quelques

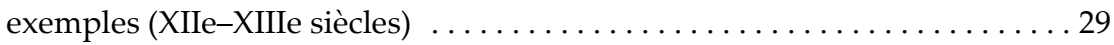

\section{Chapter 2}

\section{Susanna Niiranen}

"I know how to be a whore and thief"

The poet's reputation: troubadoursancestors of poètes maudits?

\section{Chapter 3}

Christopher R. Clason

The Law-Letter and Spirit: Language, Transgression and Justice In Three Medieval German Epic Poems

\section{Chapter 4}

\section{Stacey Hahn}

Crime, Punishment and the Hybrid in Medieval French Romance:

Robert the Devil and Geoffrey Big Tooth . . . . . . . . . . . . . . 87

\section{Chapter 5}

Scott L. Taylor

Judicium Dei, vulgaris popularisque sensus: Survival of Customary Justice and Resistance to its Displacement by the "New" Ordines iudiciorum as Evidenced by Francophonic Literature of the High Middle Ages . . . . . . . . . . . . . . . . . . . . . . . . 109 


\section{Chapter 6}

\section{Albrecht Classen}

Crime and Violence in the Middle Ages:

The Cases of Heinrich der Glichezare's Reinhard Fuchs and Wernher der Gartenære's Helmbrecht

\section{Chapter 7}

\section{John Gough}

The Function of Projected Pain: The Poetry of François Villon and the Gift of Self . . . . . . . . . . . . . . . . . . . . . . . 159

\section{Chapter 8}

Jean E. Jost

Retribution in Gamelyn: A Case in the Courts

\section{Chapter 9}

Jolanta N. Komornicka

Contra Signum Nostrum: The Symbolism of Lèse-majesté under Philip VI Valois

\section{Chapter 10}

Connie L. Scarborough

Women as Victims and Criminals in the Siete Partidas

\section{Chapter 11}

\section{Maria Cecilia Ruiz}

Theft in Juan Manuel's El Conde Lucanor

\section{Chapter 12}

Patricia Turning

Competition for the Prisoner's Body:

Wardens and Jailers in Fourteenth-Century Southern France

\section{Chapter 13}

Birgit Wiedl

The Host on the Doorstep: Perpetrators, Victims, and Bystanders in an Alleged Host Desecration in Fourteenth-Century Austria 


\section{Chapter 14}

Daniel F. Pigg

Does the Punishment Fit the Crime?: Chaucer's Physician's Tale and the Worlds of Judgment

\section{Chapter 15}

Lia B. Ross

Deviancy in the Late Middle Ages: The Crimes and Punishment of Gilles de Rais

\section{Chapter 16}

John Beusterien

The Celebratory Conical Hat in La Celestina

\section{Chapter 17}

Kathleen M. Llewellyn

Equal Opportunity Vengeance in the Heptaméron of

Marguerite de Navarre

\section{Chapter 18}

Nicolas Lombart

Crimes et Châtiments d'Exception en France au Temps des Guerres de Religion:

l'Utopie Judiciaire des Commentaires de Monluc (livres V à VII)

\section{Chapter 19}

\section{Martha Moffitt Peacock}

The Amsterdam Spinhuis and the "Art" of Correction

\section{Chapter 20}

Thomas Willard

Pimping for the Fairy Queen: Some Cozeners in

Shakespeare's England

\section{Chapter 21}

Denis Bjaï

Réflexions de Montaigne sur le châtiment des criminels 


\section{Chapter 22}

\section{Allison P. Coudert}

The Ultimate Crime: Cannibalism in Early Modern

Minds and Imaginations

\section{Chapter 23}

Evelyne Luef

Punishment Post Mortem - The Crime of Suicide

in Early Modern Austria and Sweden

List of Illustrations

Contributors .

Index

Acknowledgment and Gratitude 601 


\title{
Chapter 13
}

\author{
Birgit Wiedl \\ (Institute for Jewish History in Austria, St. Pölten)
}

\section{The Host on the Doorstep: Perpetrators, Victims, and Bystanders in an Alleged Host Desecration in Fourteenth-Century Austria}

"The body of Christ, tormented by the Jews, was found at Korneuburg on the Friday of the quarter before Michaelmas and therefore, all the Jews there were burnt." 1

In this brief sum-up in a chronicle of the Lower Austrian monastery of Klosterneuburg of what had, allegedly and for real, ${ }^{2}$ happened in the town across the river Danube, the roles are clearly defined: the Jews who had lived there had committed a crime, and had therefore been punished.

"This book is not a whodunnit," Jeremy Cohen states at the beginning of the introduction to his book Christ Killers. ${ }^{3}$ The question, if applicable at all to a historic

1 Österreichische Nationalbibliothek (Austrian National Library), Codex 364, fol. 135v (a later addition to a Salzburg chronicle in a manuscript from the monastery of Klosterneuburg, now kept at the Austrian National Library); Eveline Brugger and Birgit Wiedl, Regesten zur Geschichte der Juden in Österreich im Mittelalter, vol. 1: Von den Anfängen bis 1338 (Innsbruck, Vienna, and Bolzano: StudienVerlag, 2005), 123-24, no. 131 (for the internet version, see

http://www.injoest.ac.at/upload/Regesten_Text.pdf(last accessed on March 10, 2012). The research was funded by the Austrian Science Fund (FWF): P 21237-G18. I would like to thank Connie Scarborough for her valuable comments and corrections.

2 On the truthfulness of historiography and literature and its relation to historical texts, see the discussion by Peter Johanek, "Die Wahrheit der mittelalterlichen Historiographen," Historisches und fiktionales Erzählen im Mittelalter, ed. Fritz Peter Knapp and Manuela Niesner. Schriften zur Literaturwissenschaft, 19 (Berlin: Duncker \& Humblot, 2002), 9-26.

3 Jeremy Cohen, Christ Killers: The Jews and the Passion from the Bible to the Big Screen (New York and Oxford: Oxford University Press, 2007). In the introduction to her book Gentile Tales, Miri Rubin discusses the 'tedious type of prose' that is a result of all the 'disclaimers such as 'it was alleged", 
scenario, has been sufficiently answered. Although motives, triggers, and courses of action remain open to discussion, there is no doubt as to the fatal role (most of) the Christian authorities and/or neighbours played in the persecution and murdering of medieval Jews; while from a medieval Christian perspective, the ideas of Jewish crime, ${ }^{4}$ Jewish guilt, and the existence of crimes that Jews were particularly partial to, were hardly questioned. ${ }^{5}$ From the seducer of Christians who lures these back to the old, false faith, the fake convert who secretly indulges in their old suspicious rites, and the merciless usurer $^{6}$ to the general questionability of Jewish existence in general, Jewish crimes were manifold. ${ }^{7}$ Jews

Miri Rubin, Gentile Tales: The Narrative Assault on Late Medieval Jews (New Haven, CT, and London: Yale University Press, 1999; sec. ed. Philadelphia: University of Pennsylvania Press, 2004, the quotes herein refer to the first edition), 3.

4

For a quite exceptional case study on 'real' Jewish crime, the story of a 'gang' of Jewish thieves, see Jörg Müller, "Eine jüdische Diebesbande im Südwesten des Reiches in der ersten Hälfte des 14. Jahrhunderts," Beziehungsnetze aschkenasischer Juden während des Mittelalters und der frühen Neuzeit, ed. idem. Forschungen zur Geschichte der Juden, Abteilung A: Abhandlungen, 20 (Hanover: Verlag Hahnsche Buchhandlung, 2008), 71-116.

5 For a summary of scholarly Christian opinions on Jews and Judaism, see Gavin I. Langmuir, "Faith of Christians and Hostility to Jews," Christianity and Judaism, ed. Diana Wood. Studies in Church History, 29 (Oxford and Cambridge, MA: Blackwell Publishers, 1992), 77-92.

6 See, for example, Pope Innocent III to the French king Philipp II August in 1205: ...quod in regno Francorum Judei adeo insolescunt, ut, sub specie usurarie pravitatis, per quam non solum usuras, sed usuras usurarum extorquent, ecclesiarum bona et possessiones Christanorum usurpent. Solomon Grayzel, The Church and the Jews in the Thirteenth Century. A Study of Their Relations During the Years 1198-1254, Based on the Papal Letters and the Conciliar Decrees of the Period (Philadelphia: The Dropsie College for Hebrew and Cognate Learning, 1933) 104-06, no. 14; Langmuir, "Faith of Christians," 88-89 (see note 5), places the emergence of the motif of the Jew as usurer in the midtwelfth century. See the contribution of Kenneth R. Stow in the same volume, "The Good of the Church, the Good of the State: The Popes and Jewish Money," Christianity and Judaism, 237-52 (see note 5), on the identification of Jewish lending with Jewish acts of homicide against Christian society, 241; see also the overview by Robert Chazan, Medieval Stereotypes and Modern Antisemitism (Berkeley, Los Angeles, and London: University of California Press, 1997), 19-40, and particularly 35-40, who ties the usurer-image in with antigovernment sentiments. On the idea that Jews had killed Jesus out of greed, see Anna Sapir Abulafia, Christians and Jews in the Twelfth-Century Renaissance (London: Routledge, 1992), 121.

7 E.g., the combined accusations Simon de Montfort arose against the Jew Abraham of Berkhamsted in the 1250s: financial misdeeds and the desecration of an icon of the Virgin Mary (by placing it in his lavatory), see Christoph Cluse, "'Fabula ineptissima'. Die Ritualmordlegende um Adam von Bristol nach der Handschrift London, British Library, Harley 957," Aschkenas. Zeitschrift für Geschichte und Kultur der Juden, 5.2 (1995), 293-330; here 296; Anthony Bale, The Jew in the Medieval Book: English Antisemitisms 1350-1500. Cambridge Studies in Medieval Literature, 60 (Cambridge: Cambridge University Press, 2006), 8, and generally on the phenomenon of anti-Judaism and antiSemitism in a country from which the Jews were expelled already at the end of the high Middle Ages (1290), see also Cohen, Christ Killers, 103 (see note 3). 
were regarded capable of, and prone to, committing specific crimes most of which made their way into the stereotypes of anti-Semitism of later centuries. ${ }^{8}$

The ideas of Jewish responsibility and culpability for the crucifixion of Christ and the identification of Jews as historic enemies of Christianity and Christendom already lay, among other factors, at the core of the crusading assaults on the Rhineland Jewry of around 1096, ${ }^{9}$ and had evolved into an imagery of Jewish violence against Christians in general. As a result of the growing humanization, and subsequent vulnerability, of Jesus in the course of the twelfth century, the idea of the Jews killing a deity merged with the images of the murder of a real person, or its personification in the Eucharist. The image of a 'real' killing with a palpable victim was much more relatable for the common people. ${ }^{10}$ The theoreticaltheological image preached during a sermon was transformed into an image that could be brought up whenever needed, adapted to local circumstances, and repeated time and again - the idea that contemporary Jews behaved towards the host just like their forefathers had behaved towards Christ, and thus, their punishment was intended by God. ${ }^{11}$

What had, in more detail than the annals' succinct entry tells us, happened in the small Lower Austrian town of Korneuburg? On September 17, 1305, a host wafer was found either on the doorstep of the house that was occupied (and, presumably, owned) by the Jew Zerkel, or in his possession. ${ }^{12}$ Blood was seeping

8 From the vast literature on this topic, see in addition to the study of Chazan, Medieval Stereotypes (see note 6), the older but still valid overviews by Gavin I. Langmuir, Toward a Definition of Antisemitism (Berkeley, Los Angeles, and Oxford: University of California Press, 1990), particularly 301-10, and Stefan Rohrbacher and Michael Schmidt, Judenbilder: Kulturgeschichte antijüdischer Mythen und antisemitischer Vorurteil. kulturen\&ideen. rowohlts enzyklopädie (Reinbek bei Hamburg: rowohlt, 1991).

9 Chazan, Medieval Stereotypes, 59 (see note 6).

10 Cohen, Christ Killers (see note 3), addresses the topic in several chapters; see further Sapir Abulafia, Christians and Jews, 107-22 (see note 6), mainly on the development of the theological idea; Björn Berghausen, 'Das Lied von Deggendorf,' Juden in der deutschen Literatur des Mittelalter: Religiöse Konzepte-Feindbilder - Rechtfertigungen, ed. Ursula Schulz (Tübingen: Max Niemeyer Verlag, 2002), 233-53; here 238-39.

11 František Graus, Pest, Geissler, Judenmorde: Das 14. Jahrhundert als Krisenzeit. Sec. ed., Veröffentlichungen des Max-Planck-Instituts für Geschichte, 86 (Göttingen: Vandenhoeck \& Ruprecht, 1988), 289-90.

12 The incident(s) at Korneuburg have frequently been subject to academic analysis; see most notably Winfried Stelzer, "Am Beispiel Korneuburg: Der angebliche Hostienfrevel österreichischer Juden von 1305 und seine Quellen," Österreich im Mittelalter. Bausteine zu einer revidierten Gesamtdarstellung, ed. Willibald Rosner. Studien und Forschungen aus dem Niederösterreichischen Institut für Landeskunde, 26, Niederösterreichische Schriften, 109, Wissenschaft. (St. Pölten: Niederösterreichisches Institut für Landeskunde, 1999), 309-48, reg. the dating 323-24, with fn. 43; in the same volume, see for a summary of anti-Jewish polemics in fourteenth-century Austria Fritz Peter Knapp, “Nikolaus von Heiligenkreuz und die Judenpolemik in Österreich zu Anfang des 14. Jahrhunderts," 293-322, on Korneuburg 300-03. Further see Rubin, Gentile Tales, 57-65 (see 
from the wafer, which made it immediately clear to the bystanders that it was a miraculous object, and indeed, it started to work its first miracles right on the spot. Enraged by the obvious crime that had been committed by the Jewish inhabitants, the citizens got hold of the Jewish scholar (scolasticus) who was burnt at the stake. After that, they beat Zerkel to death, and then burnt the other Jewish inhabitants of the small town, raising the death toll to ten people altogether.

The events that led to, and ensued after, the extinction of what might have been the entire Jewish population of Korneuburg ${ }^{13}$ are exceptionally well documented. While the chronicle entry cited above merely stated the basic facts, an extensive protocol of the interrogation of twenty-one witnesses provides singularly valuable insights into both the course(s) of events and the perception(s) of these. ${ }^{14}$ About three months after the incident, in December 1305, a commission of clerics under the leadership of the Cistercian Ambrose of Heiligenkreuz (a monastery about 20 kilometres south-west of Vienna) looked into the merits of the case of Korneuburg's miracle-working host wafer and the larger issues connected with it. In the course of six days, the witnesses, six clerics and fifteen lay persons, were presented with a detailed catalogue of questions, the main focus of which was to ascertain the authenticity (or not) of the host's miraculous character and the quality of the miracles it worked. ${ }^{15}$ Therefore, the questions focussed mainly on the

note 3); Eveline Brugger, “Korneuburg 1305," Nicht in einem Bett-Juden und Christen in Mittelalter und Frühneuzeit, ed. Institute for Jewish History in Austria (Vienna: rema print, 2005), 20-26 (for the internet version, see:

http://www.injoest.ac.at/upload/JudeninME05_2_19-26.pdf, last accessed on March 10, 2012); eadem, "Von der Ansiedlung bis zur Vertreibung -Juden in Österreich im Mittelalter," Geschichte der Juden in Österreich, eadem, Martha Keil, Christoph Lind, Albert Lichtblau, and Barbara Staudinger. Österreichische Geschichte, 15, ed. Herwig Wolfram (Vienna: Ueberreuter, 2006), 123-227; here 211-16.

13 Stelzer, "Am Beispiel Korneuburg," 340 (see note 12), argues against this and points out that Ambrose in his treatise that was written about seven years after the incidents referred to the ten killed people ex iudeis and thus indicated that more Jews had lived at Korneuburg at that time. It is however possible that, since the number ten referred to the Jews who had been burnt, Zerkel, who had been beaten to death, was not included. There is no notion of any continuous Jewish presence in Korneuburg for the remainder of the century, see Germania Judaica, vol. III: 1350-1519, part 1: Aach-Lychen, ed. Arye Maimon and Yacov Guggenheim (Tübingen: J. C. B. Mohr, 1987), 674 , lists, albeit relying on rather problematic sources, altogether nine (mainly Viennese) Jews for the timespan from 1350 to 1420 that were named after Neunburg, which could either mean Klosterneuburg or Korneuburg.

Haus-, Hof- und Staatsarchiv (HHStA, Austrian State Archives), Notariatsinstrument des Notars Otto von Rußbach, AUR 1305 XII 17; full edition by Brugger and Wiedl, Regesten 1, 125-42, no. 133 (see note 1 ).

The commission consisted of four of the episcopal chaplains: Gottfried, Dean of Krems, magister albert, canon of Regensburg, the legally trained magister Konrad von Steinheim, and the notary Otto von Rußbach, who wrote (final version of) the protocol (Brugger and Wiedl, Regesten 1, 125, no. 133 and 144, no. 135 [see note 1]). On the catalogue of questions, see Stelzer, "Am Beispiel 
host wafer, its condition when it was found, and the miracles it worked after it had been installed at the parish church; which also meant after the Jews had been killed. The Jews' fate seemed of secondary, if not altogether negligible, importance to the interrogators whose main concern was whether the wafer had been consecrated or not, meaning, whether the Christians who venerated it were venerating an appropriately consecrated host. Ambrose of Heiligenkreuz, generally sceptical of miraculous hosts, had serious doubts about this. With respect to the Jews and their fate, both questions and answers remained ambiguous, and it is remarkable that none of the interrogators probed into these ambiguities and inconsistencies that appeared as the interrogation continued. $I$ don't know, or, I haven't seen it, but I firmly believe it, soon turned out to be the default replies the witnesses uttered whenever asked whether they had actually seen the host wafer work miracles, or the Jews maltreat it, rendering most of the witnesses' testimonies what we understand as the modern concept of hearsay.

Many of the testimonies contained not only inaccuracies but blatantly contradicted each other, without, however, causing the interrogators to inquire any further. There was no consistency among the answers to the question about how many eyewitnesses there had been to the discovery of the host. The first witness, the Vicar of Korneuburg by the name of Friedrich, who, while not having witnessed much of the whole incident himself, knew of 200 people being present when the bloodied host was found (et alii quasi CCti, quorum nomina nescit) - which would, if taken literally, quite likely amount to the entire population of the small town. Despite this suspiciously high number, he was only able to give the names of three witnesses, but knew that one of these, the cobbler's wife, prevented the wafer from being blown away by covering it with a cloth. ${ }^{16}$

In many of the (mostly later) tales of Jews allegedly maltreating host wafers, one of the main concerns involves how the Jews managed to acquire the wafer. Since these were kept in a space not readily accessibly to them, getting hold of a consecrated wafer would require a certain amount of scheming on their part. Mere possession of a wafer alone, without any signs of it having been maltreated, was deemed sufficient proof to justify persecution, even if this possession was only suspected, or claimed by others. The process of acquiring however usually required a Christian accomplice, who, often for pecuniary reasons, stole the consecrated wafer from a church or chapel. Quite often a woman or a girl, ${ }^{17}$ the

Korneuburg," 321-22 (see note 12); Rubin, Gentile Tales, 61-62 (see note 3); see also Wolfgang Stefan Koller, Die Korneuburger Bluthostie. Historische Quellen und Wirkung. Unpublished master thesis, Vienna 1991, appendix (table of the testimonies).

16 Reg. the questioning of the priest Friedrich, vicar of Korneuburg (first witness): Brugger and Wiedl, Regesten 1, 126, no. 133 (see note 1).

17 Wolfgang Treue, "Schlechte und gute Christen: Zur Rolle von Christen in antijüdischen Ritualmord- und Hostienschändungslegenden," Aschkenas. Zeitschrift für Geschichte und Kultur des 
Christian offender was usually of a low social standing, and the thief's fate was closely linked with the fate of the Jewish perpetrators. Her (or his) offence against the Christian faith is no less grave than the Jews', and thus the punishment meted out often matched that of the Jews, ${ }^{18}$ unless divine justice itself intervened. ${ }^{19}$

In the Korneuburg case, however, the question of how the Jews came to posses the host wafer, and for how long the host had been in their hands, seemed of surprisingly secondary importance; and the striking inconsistencies in the witnesses' answers were not investigated any further. The fifth witness, Konrad, the vicar of Leobendorf (a hamlet north of Korneuburg), declared that he knew that three years ago, the Jews had bought the host wafer for ten pounds from a layperson, the identity of whom he would not reveal since that person had told him about this during confession, although the penitent had asked him to inform the population since he felt remorse about his sinful deed. Konrad remains the only one who comes up with this version in detail, the significance of which will be discussed later. ${ }^{20}$ Konrad's version is corroborated by other witnesses: the priest Friedrich, who owned to having known about the confession from, as he said, two priests and other people, Konrad an der Hochstrass (de Alta Strata), one of the three whom Friedrich named as having been present when the wafer was found, and Otto an dem Roßmarkt.

Judentums, 2.1 (1995), 95-116; here 97; Rubin, Gentile Tales, 31-32 (see note 3); Friedrich Lotter, "Hostienfrevelvorwurf und Blutwunderfälschung bei den Judenverfolgungen von 1298 ("Rintfleisch") und 1336-1338 ("Armleder")," Fälschungen im Mittelalter. MGH Schriften, 33/5: Fingierte Briefe, Frömmigkeit und Fälschung, Realienfälschungen (Hanover: Hahnsche Buchhandlung, 1988), 533-83; here 542; on the connection of medieval misogyny and anti-Judaism, see Joan Young Gregg, Devils, Women, and Jews. Reflections of the Other in Medieval Sermon Stories (Binghamton, NY: State University of New York Press, 1997).

18 Treue, "Schlechte und gute Christen," 107-08 (see note 17).

19 Quite a "model example" is the story told by (allegedly) the Dominican Rudolf von Schlettstadt that combines several anti-Jewish images: After seducing his Christian maidservant, a nefarious Jew offered the fatuous girl lots of gold for a consecrated host which he maltreated; when his misdeeds were uncovered and he was imprisoned, he bribed the local judge (Schulthei $\beta$ ) to set him free again. By divine intervention, the town was devastated by biblical plagues, and on the third day, the judge was struck by lightning; see Johannes Grabmayer, "Rudolf von Schlettstadt und das aschkenasische Judentum um 1300," Aschkenas. Zeitschrift für Geschichte und Kultur der Juden, 4.2 (1994), 301-36; here 325-26; see also Rubin, Gentile Tales, 84-85 (see note 3). The authorship of Rudolf von Schlettstadt has been disproved by Stefan Georges, Graf Wilhelm Werner von Zimmern als Historiensammler: Die Wundergeschichtensammlung des neuentdeckten, autographen Sigmaringer Codex 64. MA thesis, Freiburg im Breisgau 1999, particularly 55-57, who is working on an edition of the codex.

20 Questioning of Konrad, vicar of Leobendorf (fifth witness): Brugger and Wiedl, Regesten 1, 130, no. 133 (see note 1 ). 
The latter two gave evidence of the scholar's death and his last words ${ }^{21}$ : upon being dragged to the stake by the enraged masses, the scholar not only claimed that he was about to die an innocent death but also accused Zerkel of having bought the host three years ago, at Christmas, from a Christian servant for the price of three solidi and a tunic, according to Otto's rendition of the scholar's words - a contradiction to the vicar's testimony who spoke of ten pounds. When Zerkel wanted to get rid of the wafer, he offered a Christian by the name of Ribaldus two pounds if the latter threw the wafer into the Danube; yet upon seeing the wafer in the Jew's hands, Ribaldus exclaimed that this was his creator whom he would not touch for a thousand talents (hoc est creator meus, hunc ego non tangam eciam pro mille talentis).

These quite detailed versions tie in in some parts with what can be derived from most of the testimonies that were less elaborate. Most of the witnesses who gave any statement as to how the Jews came into possession of the wafer, and as to how that possession was discovered, did not mention a prior purchase but concurred that on the fateful day, they had seen Zerkel run after a Christian, accusing him of having thrown the host into his house only a few moments ago. The Jewish scholar was following them, carrying the bloodied wafer, which he had presumably picked up from the threshold, in his hands, or wrapped in a cloth, and was begging the surrounding Christians to take it from him. Konrad an der Hochstrass and another witness, the carpenter Sidlo, gave what they claimed to be the exact words the scholar yelled at the gaping bystanders: "Take your god," he allegedly had screamed, "whom that servant has brought into our house, he [the servant] who should rather burn than us."22

The Christians who observed the scene however refused to take the host, and when the scholar threw it to the ground, Zerkel trod on it repeatedly. ${ }^{23}$ The

21

Questioning of Konrad an der Hochstrass (seventh witness) and of Otto an dem Roßmarkt (eigth witness): Brugger and Wiedl, Regesten 1, 132, 134, no. 133 (see note 1).

22

Questioning of Konrad an der Hochstrass (seventh witness), and of the carpenter Sidlo (fourtheenth witness): Brugger and Wiedl, Regesten 1, 132, 139, no. 133 (see note 1).

23

The image of Jews maltreating a host wafer by treading on it is a rather rare image, but is vividly exemplified in an incident reported by an English Dominican that had supposedly happened during the German 'Armleder' persecutions: A Jew, who had beforehand bought a host wafer from a knight, mocked the worshippers during the Corpus Christi procession by insisting that he "kept Christ under his foot in his shoe." When he was slain immediately by a bystanding knight, the bloodied host was found in the sole of his shoe, leading to a wide-ranging persecution of the Jews "wherever they could be found in the area." See for an extensive discussion of the motif, Christoph Cluse, 'Blut ist im Schuh. Ein Exempel zur Judenverfolgung des "Rex Armleder."' Liber Amicorum necnon et amicarum. Für Alfred Heit: Beiträge zur mittelalterlichen Geschichte und geschichtlichen Landeskunde, ed. Friedhelm Burgard, Christoph Cluse, and Alfred Haverkamp. Trierer Historische Forschungen, 28 (Trier: Verlag Trierer Historische Forschungen, 1996), 371-92 (with an edition of the text, 379). 
question of why Zerkel, if he had acquired the host wafer three years ago, would have decided to get rid of it now, is never asked; and the question why, in particular, he would take a bloodied host he had owned for years in his hands and run through the streets of Korneuburg is not even touched upon. The detail however that most of the witnesses agree upon, that they witnessed Zerkel and the scholar as they ran after the Christian and shouted that he had planted the wafer at their doorstep, sounds all the more believable. The panicked Jews ran through the streets of the town with the wafer in their hands, hoping against all odds that they would be exculpated when the real perpetrator was caught. Their awareness of the immediate danger when they found the bloodied wafer on their threshold is reflected in Otto's testimony, albeit with a twist: the Jews were, according to the scholar's last words, well aware of their guilt and well deserved their punishment (nos merimus illam penam in Deo vestro).

Another version of how the wafer had made its presence known made use of the already well-established topic of heavenly assistance. ${ }^{24}$ Sifridus or Sidlinus, a baker at Korneuburg, claimed in his testimony that while he was at work (in actu pistandi), he heard a voice that urged him to go to Zerkel's house, and when he hesitated, he was suddenly grasped by a force that all but dragged him 'under the Jew's door,' sub portam iudei. ${ }^{25}$ Upon arriving there, he saw the wafer lying on the ground, 'sweating beautiful blood and blistering' (vidit corpus Domini sudare sanguinem pulcherrimum et bullire guttatim). He stood mesmerized, but when his gaze drifted back to the street (indicating that he had entered the Jew's house?), ${ }^{26}$ the wafer suddenly appeared between his thumb and index finger, and he put it down onto the doorstep of the Jews' house while a small dot of blood remained on his finger. In the meantime, two other witnesses had gathered around him, Bertha, the wife of Konrad Reus, and another woman, Shellerin; a blatant contradiction to several other versions of who had (allegedly) been present when the wafer had been found. It seems that a crowd had gathered rather quickly, which might explain some of the inaccuracies, yet even the testimonies of those who claimed that they had been immediate witnesses are at variance.

The three witnesses to the retrieval that were named by the priest Friedrich are not mentioned by others, while these three-the cobbler's wife, Konrad an der Hochstrass, and Sidlo-either were not questioned at all (the cobbler's wife), or did not give any names. The members of the town council, who had been in a meeting, came running to the Jew's house upon hearing the turmoil, which had

24

25

26

Lotter, "Hostienfrevelvorwurf," with several examples throughout the article (see note 17). Questioning of Sifridus/Sidlin (eleventh witness): Brugger and Wiedl, Regesten 1, 137-38, no. 133 (see note 1 ).

Stelzer, "Am Beispiel Korneuburg," 327 (see note 12), suspects this according to Sidlin's wording (eoque respiciente per portam ad stratam vidit hostiam predictam in duobus digitis). 
also attracted many others, the majority of whom remained unnamed (and uninterrogated). Furthermore, contradictions about who could provide immediate knowledge of the events were not solved. The carpenter Sidlo, who had been named by Friedrich as one of the eyewitnesses to the discovery, himself declared that he had only left his house, where he had been at work, when he had heard the Jew calling out 'catch him.' Upon entering the street he had seen three Jews running along the street, amongst them the scholar, who had been carrying a cloth from which blood was dripping, which he wiped on his chest. He did not witness, according to his own statement, the actual discovery (neither by the heavenly guided baker nor by Zerkel) of the wafer. ${ }^{27}$

The testimony given by the tenth witness, Heinrich Shem, sheds yet another, surprising, light on the scene. Although when facing the commission, Heinrich emphasized his firm belief in the authenticity of the host and his abhorrence of the Jews' crime, his statement nevertheless speaks of a distinct personal acquaintance with the Jews. He was in Zerkel's house at the time the host was discovered (which the interrogators did not comment on) and he saw it lying on the doorstep and bubbling blood-drops "like an egg that sweats when it is cooked." His testimony not only supported the Jews' claim that the wafer had been planted at their doorstep but also showed clearly that the Jews were absolutely, and immediately, aware of the fact that this had been a malicious action aimed at them: o domine Henrice, Zerkel called out to him, "this evil man threw the body of your God into my house and slipped away" (ecce quidam vilis homo proiecit corpus Dei vestri ad domum meam et recessit).

Upon seeing the bloodied wafer, though, Heinrich immediately blamed the Jews for it (which Zerkel denied), yet he still admitted to having urged Zerkel to flee, but, he added, not without telling the Jew that he would not be able to escape. Two other citizens, both named Marquard, and members of the town council then ushered Zerkel into the house of Konrad Reus and hid him, telling him to remain there. Yet when the populace returned from burning the scholar, who, as they claimed, had in dying named Zerkel as the sole perpetrator, they broke into Reus's house, dragged him out, and beat him to death.

Then the angry masses proceeded to kill the other Jews, both men and women. ${ }^{28}$ The significance of Heinrich Shem's testimony is noteworthy in many regards: several of his statements are blatantly at odds with each other, and his answers may reflect a desire to please the commission. Even more surprising is that although the Marquardus who was interrogated as the sixteenth witness can quite likely be identified as one of the two Marquards, his testimony is nevertheless

Questioning of Sidlo (fourtenth witness): Brugger and Wiedl, Regesten 1, 139, no. 133 (see note 1). Questioning of Heinrich Shem (tenth witness): Brugger and Wiedl, Regesten 1, 136, no. 133 (see note 1). 
reduced to very few basic facts - that he, along with other members of the sworn council alerted by the clamor, arrived at Zerkel's house to see the bloodied wafer at the doorstep, which he firmly believed to be the genuine body of Christ. ${ }^{29}$

Neither the minutes of the interrogation nor any of the later sources hint at him and his namesake being accused of helping the Jew, nor at any repercussions against them and Heinrich Shem. Konrad Reus, who quite likely was not present during the whole incident, was not consulted as a witness, ${ }^{30}$ whereas his wife Bertha, who had been present during the discovery of the wafer, was at no point asked about Zerkel having been brought to her house but was presented with the standard catalogue of questions.

While Zerkel hid in Konrad Reus's house, the host worked its second miracle (after bleeding as a consequence of the treatment it allegedly suffered from the Jews' hands) even before it was taken to the parish church. The scholar's hand, that had held the host during his panic-induced chase through the streets, remained unmarred by the fire. ${ }^{31}$ Installed then at the parish church by the priest Friedrich (while the Jews met their tragic fate), ${ }^{32}$ it continued to work all kinds of miracles that were listed in detail by the majority of the citizens questioned. ${ }^{33}$ The series of miracles the host worked at the church seem to have started on the Sunday after the incidents with the spontaneous lighting of six candles, yet more imposing miracles were about to start another week later. According to the vicar Friedrich, Gertrudis, a young woman of about 20 years, was cured of her blindness on Michaelmas (September 29) when the piece of cloth was placed over her eyes

29 Questioning of Marquardus, member of the town council (sixteenth witness), Brugger and Wiedl, Regesten 1, 140-41, no. 133 (see note 1).

30 It is not clear whether Konrad Reus is still alive at this time. He is mentioned only in 1293 and 1298 (Urkundenbuch des Stiftes Klosterneuburg bis zum Ende des vierzehnten Jahrhunderts, vol. 1, ed. Hartmann Zeibig Fontes Rerum Austriacarum - Österreichische Geschichtsquellen. Zweite Abtheilung: Diplomata et Acta, X [Vienna: Kaiserlich-Königliche Staatsdruckerei, 1857], 45, no. $51,59-60$, no. 66), but since Bertha Reusin is referred to as his wife and not widow, it is more likely that he was still alive but not at home.

31 Questioning of Konrad von Leobersdorf (fifth witness): Item dixit sibi constare ex auditu nobilium et clericorum, quod sanguis distillavit de manu iudei tenentis hostiam in manu et quod cremato predicto iudeo, de cuius manu distillavit dictus sanguis manus eadem dicti iudei, qua hostiam tenuerat, incombusta remansit; and of Konrad an der Hochstrass (seventh witness): manus eadem [the Jewish scholar's], qua corpus Domini tenu[er]at incombusta remansit. Brugger and Wiedl, Regesten 1, 130 and 132, no. 133 (see note 1 ).

32 Questioning of Heinrich Plichel (twelfth witness): upon arriving at the scene, Friedrich took the wafer and carried it ad primum locum, presumably the parish church. Stelzer, "Am Beispiel Korneuburg," 327 (see note 12), Brugger and Wiedl, Regesten 1, 138, no. 133 (see note 1). For a detailed list of the miracles, see Koller, Korneuburger Bluthostie, appendix A (candles), B (blind), C (possessed), and D (handicapped) (see note 16), and, with some errors, Franz Zeissl, Das ehemalige Augustinerkloster in Korneuburg, Korneuburger Kulturnachrichten 27 (1965, special issue), $4-5$. 
at the Jews' house (!). Two other witnesses also reported the healing of one or two girls who were shown the cloth at the Jews' house on that day, yet denied any knowledge of their names and gave quite differing statements as to how long the girl(s) had been blind.

Inconsistencies such as these hamper any definite identification of the (allegedly) cured, yet obviously did not bother the commission. Even more spectacular though, and attracting the presence of such noble witnesses as Otto von Zelking and members of the families of Maissau and Wallsee, was the healing of a fourteen-year-old Bohemian girl possessed by three demons who was shown the host at the altar of the church. According to other witnesses, a man from Vienna and a woman who were shown the cloth at the Jews' house (where the cloth seems to have been kept) and thus freed of their demons. Within only a fortnight, the rumor of the existence of a miraculous host wafer had spread, and other miracles ensued, such as the healing of the Viennese tailors Konrad and Ramungus of Stein, as well as Sifridus and Witigo of Bruck, who had all their vision returned after either having been shown the host and/or the cloth, or by the mere presence of the holy object, around Saint Koloman's Day (October 13) and during Advent.

The powers of the miraculous host were not limited to restoring sight, however. The local weaver Pero, crippled for some years, a handicapped boy called Chunzelinus Schoderleh, the local innkeeper Tasco's son Bruno, paralysed since infancy and only able to "crawl like a reptile," the Viennese woman Alheit Hutterin, paralysed for eight years, Ebermannus from Klosterneuburg, with a paralysed foot, were all healed by looking at the host, or the shrine, while the Viennese woman Gertrud, who had been unable to walk for six years, regained her mobility without being in the presence of the host at all. There is no further mention of the cloth being shown at the Jews' house, suggesting that it had been incorporated into the shrine that had obviously been erected for the host in the meantime.

Only some of the witnesses though were able to give these names, and even fewer could include any further details. Most witnesses either assured that they "had heard about it [the respective handicap and/or the healing] for sure," yet again resorting to quoting hearsay, or, for the most part, cited the healing of blind, lame, and paralysed people who remained anonymous. Neither the cured nor any of the non-local witnesses to the lighting and healing miracles were called in for interrogation, which might come as a surprise given how centred the enquiry was on the question of the authenticity of the host and its miraculous work.

The incidents at Korneuburg fall into the category of a spontaneous persecution of Jews. ${ }^{34}$ In the course of the late middle ages, host wafer desecration and/or 
blood libels served as the most common reasons for violent outbreaks against Jews on local as well as regional scales. ${ }^{35}$ In the Austrian territories, alleged host desecration became the most common accusation to trigger a persecution, while the ritual murder accusation, although not unheard of in Austria, was more frequently made use of in other territories in the German-speaking realm. ${ }^{36}$ The instigators of these persecutions however vary. The infamous Rintfleisch pogroms, starting off with an alleged host desecration in the small town of Röttingen and wreaking havoc on the Jewish communities mainly in Franconia in 1298, had been carried out not solely, but mainly by members of the lower classes. ${ }^{37}$

Many of the later persecutions were approved of, or even incited, not only by local authorities, such as municipalities or the lord of the town, but also by the rulers of the respective territories. In contrast to this, the persecutions that sprung up in the Austrian regions until the mid-fourteenth century were carried out solely by the local population, the same people that had, in most of the towns and rural areas, lived side by side rather peacefully with their Jewish neighbors. Immediate vicinity of Jews and Christians was inevitable in the close-knit structures of cities, and the contacts and relationships were quite likely even closer in the rural villages where a small Jewish population, consisting of perhaps one or two families, would need to interact with the surrounding Christian population on a daily basis. ${ }^{38}$ There is sufficient evidence that indicates peaceful neighborly

35 Michael Toch, "Spätmittelalterliche Rahmenbedingungen jüdischer Existenz: Die Verfolgungen," Hofjuden und Landjuden: Jüdisches Leben in der Frühen Neuzeit, ed. Sabine Hödl, Peter Rauscher, and Barbara Staudinger (Berlin and Vienna: Philo, 2004), 19-64; here 44.

36 Still basic for the German-speaking area is the article by Lotter, "Hostienfrevelvorwurf," 548 (see note 17); see also Langmuir, Toward a Definition of Antisemitism, 120-33 and 263-81 (see note 8); Rainer Erb, "Zur Erforschung der europäischen Ritualmordbeschuldigungen," Die Legende vom Ritualmord. Zur Geschichte der Blutbeschuldigung gegen Juden, ed. idem. Dokumente, Texte, Materialien, Zentrum für Antisemitismusforschung der Technischen Universität Berlin, 6 (Berlin: Metropol, 1993), 9-16; and Israel Jacob Yuval, Two Nations in Your Womb: Perceptions of Jews and Christians in Late Antiquity and the Middle Ages, trans. from the Hebrew by Barbara Harshav and Jonathan Chipman (2000; Berkeley, Los Angeles, and London: University of California Press, 2006), 170-73.

37 Lotter, “Hostienfrevelvorwurf,” 548-59 (see note 17), and “Die Judenverfolgung des „König Rintfleisch" in Franken um 1298. Die endgültige Wende in den christlich-jüdischen Beziehungen im deutschen Reich des Mittelalters," Zeitschrift für historische Forschung, 4 (1988), 385-422; Graus, Pest, Geissler, Judenmorde, 290-92 (see note 11).

38 For the duchy of Austria, see Eveline Brugger, "Neighbours, Business Partners, Victims: JewishChristian interaction in Austrian towns during the persecutions of the fourteenth century," Intricate Interfaith Networks: Quotidian Jewish-Christian Contacts in the Middle Ages, ed. Ephraim Shoam-Steiner (Brepols: Turnhout, 2011) [in print]. See also Jonathan Elukin, Living Together -Living Apart. Rethinking Jewish-Christian Relations in the Middle Ages (Princeton: Princeton University Press, 2007), 84-85 and the discussion the book caused, for example the reviews by Michael Toch, The Catholic Historical Review 95.3 (2009), 604-07, and, aiming at a broader audience, David Nirenberg, "Hope's Mistakes," The New Republic, 13 February, 2008 (for the internet 
cohabition over a long time period, yet the incidents at Korneuburg clearly show how fragile the relations between Jews and Christians were. Given the right catalyst, such as a bloodstained wafer, once added to the mix, the normalcy of everyday relations could suddenly erupt into violence. ${ }^{39}$

The (re-)killing of Christ as one of, if not the most abominable of all the Jewish crimes, could be executed in various forms in Christian fantasies. Yet whereas the tales of Jewish ritual murder, the horrendous blood libel accusations that quickly spread throughout the Ashkenazic region in mid-twelfth century, ${ }^{40}$ merely played with the equation of the killing of a Christian child and the death of Christ himself, the host wafer actually was the body of Christ. ${ }^{41}$ This was enhanced by the

version, see https://webshare.uchicago.edu/users/nirenberg/Public/hopes-mistakes.pdf, last accessed on March 10, 2012).

39 Bale, Jew in the Medieval Book, 5, plate 1 (see note 7), gives the example of an anti-Jewish illustration in a business document. See also Johannes Heil, "Gottesfeinde" - "Menschenfeinde": Die Vorstellung von jüdischer Weltverschwörung (13.-16. Jahrhundert). Antisemitismus: Geschichte und Strukturen, 3 (Essen: Klartext-Verlag, 2006), 60-62; with reference to Austria and Korneuburg, see Brugger, "Neighbours, Business Partners, Victims" (see note 38).

For an overview of the vast discussion, see Cohen, Christ Killers (see note 3), the anthology by Erb, Legende vom Ritualmord (see note 36); Ronnie Po-Chia Hsia, The Myth of Ritual Murder: Jews and Magic in Reformation Germany (New Haven, CT: Yale University Press, 1988); Gerd Mentgen, "Über den Ursprung der Ritualmordfabel," Aschkenas. Zeitschrift für Geschichte und Kultur der Juden, 4 (1994), 1-12; Jeffrey Cohen, "The Flow of the Blood in Norwich," Speculum, 79 (2004), S. 26-65; John M. McCullouh, “Jewish Ritual Murder: William of Norwich, Thomas of Monmouth, and the early dissemination of the myth," Speculum, 72.2 (1997), 684-740; here 700, argues that the early ritual murder accusations represent "an important stage in the increasingly negative attitudes of the majority toward the minority" in the sense that the myth aided to justify Christian hostility by establishing the concept of a continuance of Jewish enmity toward Christ since their 'first' killing of him; a development that went hand in hand with a decline in the Jews' legal status as well as economic restrictions; a finding that, however, reflects the situation in England while it took another century for a similar development to take place in the German-speaking territories. On the 'origin' of the concept of Jews committing ritual murders and the discussion whether it was 'invented' by Thomas of Monmouth, or, as suggested by Israel Jacob Yuval, 'imported' from the continent, 699-700, and 731-32 on the 1147 case of Theodoric of Würzburg; see also Chazan, Medieval Stereotypes, 59-60 (see note 6) (with an English translation of the chronicle entry); On the general situation of the Jews in England at this time, see Joe Hillaby, "Jewish Colonisation in the Twelfth Century," The Jews in Medieval Britain: Historical, Literary and Archaeological Perspectives, ed. Patricia Skinner (Woodbridge, Suffolk: The Boydell Press, 2003), 15-40; here 20-25. The first blood libel accusation in the realm of the Holy Roman Empire was raised in Fulda in 1236, see Bernhard Diestelkamp, "Der Vorwurf des Ritualmordes gegen Juden" Religiöse Devianz. Untersuchungen zu sozialen, rechtlichen und theologischen Reaktionen auf religiöse Abweichung im westlichen und östlichen Mittelalter, ed. Dieter Simon. Ius Commune, Sonderhefte: Studien zur Europäischen Rechtsgeschichte, 48 (Frankfurt a. M.: Vittorio Klostermann, 1990), 19-40; see also Langmuir's discussion in Toward a Definition of Antisemitism, 263-81 (see note 8).

Heil, "Gottesfeinde" - "Menschenfeinde," 242-43 (see note 38). In an interesting and telling twist, the accusation against the Jews of the central Rhine area of having murdered the boy Werner of Oberwesel ("Good Werner") around Easter 1287 that had led to the worst pogrom since the First Crusade in this region was remodelled at the beginning of the fourteenth century: the Jews now 
development of a popular piety that increasingly focused on objects of veneration and was especially concerned with their vulnerability to desecration. When the consecrated host was mutilated, stabbed, torn to pieces, thrown into the dirt, into a lavatory, or a well, trampled on, and eventually destroyed, this act was perceived as an re-enactment of the killing of Christ. ${ }^{42}$ Thus, on a theological scale, host wafer desecrations were considered an even more abhorrent offence than any other Jewish crime. It was, as the Korneuburg incident, and many more to follow, would prove, also the least laborious way to generate an outburst of anti-Jewish violence. $^{43}$

Given how little time had passed between the first accusation of host desecration that had been raised in 1290 in the considerably far away city of Paris, ${ }^{44}$ it is remarkable how quickly these tales had reached the small town at the utmost east of the Holy Roman Empire. ${ }^{45}$ Yet in 1305, these accusations were already familiar to the Korneuburg inhabitants, both Christians and Jews, perhaps because of a rather close-by incident. Eleven years earlier, in 1294, Jews at Laa an der Thaya, about 45 kilometres north of Korneuburg, had been accused of hiding a host in a stable and mangling it, and had been killed. ${ }^{46}$ It is therefore not surprising that both Zerkel and the scholar were instantly aware when they found the host on the doorstep that they were in mortal danger, and they were correct. Even if the legend of the host wafer desecration by Jews had found its first full execution only a mere one and a half decade earlier, the main elements of the narrative had long

had captured and tormented Werner to get the host he had received earlier during mass, see Jörg R. Müller, "Erez geserah-'Land of Persecution': Pogroms against the Jews in the regnum Teutonicum from c. 1280 to 1350," The Jews of Europe in the Middle Ages (Tenth to Fifteenth Centuries, ed. Christoph Cluse (Turnhout: Brepols, 2004): 245-260, here 249-51.

42 Lotter, "Hostienfrevelvorwurf" (see note 17), see also Graus, Pest, Geissler, Judenmorde, 290-92 (see note 11). The tale of the alleged host desecration of Deggendorf (1338) is one of the few examples where the host was also chewed upon by the Jews - with the appearance of the holy child preventing the host from being swallowed (Berghausen, "Lied von Deggendorf," 247 [see note 10]; the text [the Augsburg rendition of 1520] is edited by Ludwig Steub, Altbayerische Culturbilder [Leipzig: Ernst Keil Verlag, 1869], part II: Der Judenmord zu Deggendorf, 21-150, the text 146-49); that this image was scarcely used is perhaps due to its closeness to the 'appropriate' Christian usage.

43 Graus, Pest, Geissler, Judenmorde, 290-91 (see note 11).

44 On the 1290 Paris telling that is considered by many as the first 'full' rendition of the host desecration tale, see Rubin, Gentile Tales, 40-48 (see note 3); Lotter, "Hostienfrevelvorwurf," particularly 536-38 (see note 17).

45 Miri Rubin, "Desecration of the Host: the Birth of an Accusation," Christianity and Judaism, 169-85; here 175-77 (see note 5); Jeremy Cohen, The Friars and the Jews. The Evolution of Medieval AntiJudaism (1982; Ithaca, NY: Cornell University Press, 1986); for a summary of later, and still ongoing, discussions regarding the role of the mendicant preachers, see Cluse, "Blut ist im Schuh," 371-73 (see note 23). note 12); Lotter, "Hostienfrevelvorwurf," 549 (see note 17). 
existed. The main patterns of the legend were followed through from Paris onward, with only slight deviations in the cast of the dramatis personae Miri Rubin has identified as the 'default' participants of the standard narrative. ${ }^{47}$

However unique the source material for Korneuburg might be, the narrative resembles established patterns. Zerkel clearly served as the main perpetrator, the Jew (in most cases male) who gained possession of the host and desecrated it. The subject of his accomplices, the question whether or not some or all of the other Jews had participated in any way in the purchase and/or desecration of the host, was introduced in a quite twisted way at Korneuburg. Those who had quite likely participated in killing the Jewish scholar (without ever admitting to it) were the ones who repeated to the commission what they claimed the scholar had said: that he had named Zerkel as the only perpetrator, the one who had committed the crime by first buying and then desecrating the host.

Even though the misled Christian who sold the host to the Jews was depicted as being deeply repentant of his sin and praying for forgiveness (as the priest Friedrich told the commission), he did not make any further appearance. The unveiling of the miraculous host however follows already established patterns. The host, as an active participant, reveals itself to the faithful, making its presence known through bleeding, as in Korneuburg, sobbing, flying away, or turning into flesh, or even appearing as a little child. ${ }^{48}$

In some versions of the tale, it is assisted by a Christian - the baker Sidlin in the Korneuburg rendition - who responds to its holiness by letting himself (or, rarely, herself) be led to the maltreated host. The "crowd and its violence" ${ }^{49}$ are, in the depictions of the ecclesiastical chronicles, the righteous counterpart to the felonious Jews, the rightfully enraged masses who not only make sure that the abuse, mockery, and, eventually, killing of Christ is avenged but also that justice

Rubin, Gentile Tales, 70-92 (see note 3); see also Lotter, "Hostienfrevelvorwurf" (see note 17), and Erb, "Zur Erforschung der europäischen Ritualmordbeschuldigungen," 10 (see note 36), on the general 'skeleton' of the legends on host desecration.

See for example the long list of torments the host wafer had to endure in the Lied von Deggendorf ('song of Deggendorf'), a late fourteenth-century rendition of the events during and after the alleged host desecration at Deggendorf in 1338 that triggered one of the most wide-ranging persecution of Bavarian Jews: the host was maltreated with hammers, pliers, and anvil, and thus, it started to bleed; it was burnt in the oven but flew away; it was chewed upon, and the child appeared; angels, doves, and/or the virgin appeared; it started to glow; and, eventually, it moaned. Berghausen, "Lied von Deggendorf," 245-46 (see note 10), Rubin, Gentile Tales, 179-81 (see note 3). For the relation with blood and the colour red, see the anthropological study by Claudine Fabre-Vassas, The Singular Beast. Jews, Christians, $\mathcal{E}$ the Pig. Trans. from the French by Carol Volk (1994; New York and Chichester: Columbia University Press, 1997), 129-59 (blood libel and host desecration accusation), 211-12 (Romanian legend of eggs, that are carried by a Jew, turning red when he passes through the market at Easter). note 3). 
is served. The punishment meted out for the Jews of Korneuburg, with the exception of Zerkel, followed the most common means of retribution - burning at the stake, on a pyre piled up within a very short time.

The interviewers, generally not all that interested in the fate of the Jews when not immediately connected with the bleeding host, did not probe any further or ask who had actually been present when the Jews were consumed by the fire. Despite the 21 interviewees, the additional names that were dropped by these during their interrogation, and the detailed knowledge the commission gained in other regards, the executing masses remained anonymous and only years later, after having learned the truth, would Ambrose of Heiligenkreuz, in his treatise on the miraculous host, scold the townspeople of Korneuburg for their rash, precipitant, and eventually unjust actions. In the Korneuburg case, another member has to be added to the cast, one who is not altogether unknown to the narrative: the priest (and village community) who profited from the establishment of a new pilgrim site in the town..$^{50}$

Christian fantasies of Jews mocking and mistreating Christian symbols were not reduced to the host wafer. In Oxford in 1268, a Jew was accused of having snatched a cross and kicked it into the mud, ${ }^{51}$ and in Vienna in 1281, a Jew was stoned for having thrown dirt and/or feces at a priest carrying an ostensory. ${ }^{52}$ These objects were also part of the anti-Jewish Christian fantasies as was the idea of Jews ritually killing images of Christ that were made of wax. ${ }^{53}$ These ideas, that were already established in the Christian mind, eventually converged with the increased importance that was attributed to the Eucharist, the feast of Corpus Christi, and the subsequent increased importance of the host wafer as a ritual object with its inherent miraculous, almost "magical" qualities. ${ }^{54}$ The transubstan

50 Graus, Pest, Geissler, Judenmorde, 293: "the local priests were both initiators and beneficiaries" (see note 11).

51 Christoph Cluse, "Stories of Breaking and Taking the Cross: A Possible Context for the Oxford Incident of 1268," Revue d'Histoire Ecclésiastique, 90.3-4 (1995), 396-442; Heil, "Gottesfeinde" "Menschenfeinde," 237-38 (see note 38).

52 Brugger and Wiedl, Regesten 1,77-78, no. 62 (see note 1); see Lotter, "Hostienfrevelvorwurf," 545 (see note 17).

53 Cluse, "Blut ist im Schuh," 375, fn. 23 (referring to a thirteenth-century anonymous collection of preach instructions from France that casually adds to the catchword "devil" the information that Jews use to crucify wax images of Christ and, sometimes, children) (see note 23); Heil, "Gottesfeinde" - "Menschenfeinde," 238 (see note 38).

54 Graus, Pest, Geissler, Judenmorde, 287 (see note 11); see also the story told by Rudolf von Schlettstadt of the converted Jewess who lists all sorts of magical practices her mother had conducted by using a host that clearly reflects Christian, and not Jewish, ideas about magical (mis)use of wafers (Grabmayer, "Rudolf von Schlettstadt," 319 [see note 19]). On the Christian (mis)use of host wafers for magical practices, see Peter Browe, "Die Eucharistie als Zaubermittel im Mittelalter," Archiv für Kulturgeschichte, 20 (1930), 134-54; and Michael David Bailey, Magic and Superstition in Europe: A Concize History from Antiquity to the Present (Landham, Boulder, New 
tiation, the turning of the bread, i.e., the host wafer, and the wine into the actual body and blood of Christ during the Consecration of the Eucharist, had been elevated to a Church dogma by the Fourth Lateran Council in 1215, which made the host wafer the most powerful device of them all since it was supposed to be a manifestation of Christ himself.

Considering these "killing of Christ" fantasies that the host desecration was based on, it is not surprising that-even if not at Korneuburg-Easter turned out to be a particularly dangerous time for Jews, even more so when it coincided with Passover. This is eerily reflected in many ecclesiastical law codes that advise Jews not to leave their houses during the high feasts of the Christians, particularly during feasts that were celebrated with processions such as those held during Corpus Christi. ${ }^{55}$

Shortly after, or perhaps already in the Paris legend, a significant paradigm shift can be perceived. The perpetrators of the earlier tales, the origins of which can be traced back to late antiquity, ${ }^{56}$ could have been Jews, but also Christians who were not firm in their belief. The crucial element was that he (or, rarely, she) was an eye witness to the host's sanctity that manifested itself in its miracles, first by enduring the ill-treatment meted out by the perpetrator unscathed, by making itself known to the public, and then by working miracles. This visualization ${ }^{57}$ of its power was what either prompted the Jew to subsequently seek baptism or the doubtful Christian to be reassured in his/her faith. ${ }^{58}$ Those Christians who might be wavering in their faith were a significant part of the target audience for these tales

York, Toronto, and Plymouth UK: Rowman \& Littlefield Publishers, 2007), 113-14 (on the host desecration accusation against Jews), 124 (on the magical use of hosts by Christians). On the "magical" presentation of said object during the eucharist and the feast of Corpus Christi, and the impact this had on the audience's ideas of Jewish host desecration, see Mitchell Merback, The Thief, the Cross and the Wheel: Pain and the Spectacle of Punishment in Medieval and Renaissance Europe (Chicago: The University of Chicago Press, 1998), 193-95; for an anthropological perspective, see Fabre-Vassas, The Singular Beast, 149-52 (see note 48).

55 See Markus Wenninger, "Das gefährliche Fest. Ostern als zeitlicher Kristallisationspunkt antijüdischen Verhaltens," Feste und Feiern im Mittelalter. Paderborner Symposium des Mediävistenverbandes, ed. Detlef Altenburg, Jörg Jarnut, and Hans-Hugo Steinhoff (Sigmaringen: Jan Thorbecke, 1991), 323-32; Heil, “Gottesfeinde" - "Menschenfeinde,, 227-33 (see note 38); FabreVassas, The Singular Beast, 149-54 (see note 48); Müller, "Land of Persecution," 247 (see note 41). Lotter, "Hostienfrevelvorwurf," 539-40 (see note 17); Heil, "Gottesfeinde" - "Menschenfeinde, " 242 (see note 38).

57 Fabre-Vassas gives evidence that the Paris incident had been turned into a play that was performed on a chariot during processions up until the sixteenth century, making the scenes - the Jew torturing the host, the long streams of blood that spurted from it, the metamorphosis into a small child - all the more impressive (Fabre-Vassas, The Singular Beast, 152-53 [see note 48]).

Lotter, "Hostienfrevelvorwurf," 539-43 (see note 17); for a specific example, see Cluse, "Blut ist im Schuh," 380 (see note 23): the tale of the Jew keeping a bloodied host wafer in his shoe is listed among other stories of miraculous hosts, and the added rubric sums up the main message that was to convey with the tales: that the presence of Christ at the altar was indeed possible. 
which were, at all times, told by Christians for Christians, with the Jews being the projection of all that was not Christian. ${ }^{59}$ The earlier concept is still reflected in the Paris version that is considered by many scholars as the first valid host desecration legend, ${ }^{60}$ where only the Jew who stole the host and mistreated it was burnt at the stake (after having been put on trial) while his wife and daughter/children and other Jews were so impressed by the miracles that they converted. ${ }^{61}$

The chance for at least some of the Jews to survive and thus to actually see the errors of their ways was crucial. Their desire for conversion, as the result of the wonders they had witnessed, serves as the narrative tool to illustrate the powers of the host wafer to which even the most obdurate gainsayers, the Jews, had to yield. Only those who had actually performed the misdeed, who prolonged their crimes by choosing to disregard the host's salvific powers and remain in their obduracy, received what they deserved. In the early tales, anti-Jewish elements appear less frequently than tales without such elements and the focus of the stories is educational: to convey the idea of the transubstantiation, the real presence of Christ in the sacrament on the altar, the veneration of the sacramental body of Christ in the host. ${ }^{62}$

While, however, tales about Christians mistreating host wafers continued to exist, ${ }^{63}$ the number of tales of the misuse of host wafers with Jewish participation grew in the course of the fourteenth century, developing out of this new Eucharistic lore and other, older tales about Jews. ${ }^{64}$ The focus of the stories broadened from showing the power of the sacrament to include the malice and obduracy of the Jews, who had transformed from being at least potentially redeemable subjects that could be gathered into the Christian fold into beings that were beyond redemption, even if they were given the chance. ${ }^{65}$

59 Bale, Jew in the Medieval Book, 2 (see note 7): "Judaism as a faith and 'Jewishness' as a repository of fantasy projections [that] were central to the self-definition of medieval Christianity."

60 See for an extensive discussion of the Paris narrative and its sources Lotter, "Hostienfrevelvorwurf," 537-36 (see note 17); Rubin, "Desecration of the Host," 169-71 (see note 45).

61 For other, similar, examples from England and France, see Cluse, "Fabula ineptissima," 296-97 (see note 7).

62 Miri Rubin, Corpus Christi. The Eucharist in Late Medieval Culture (Cambridge: Cambridge University Press, 1991), 108-29; Heil, "Gottesfeinde" - "Menschenfeinde," 243 (see note 38); see also Graus, Pest, Geissler, Judenmord, 286-88 (see note 11), with an emphasis of the "magical" qualities of the transubstantiation.

Lotter, "Hostienfrevelvorwurf," 548 (see note 17), lists 36 host miracles in the German-speaking area in the first half of the fourteenth century. 31 of these based upon desecrations, and for 24 out of these 31, Jews were blamed.

65 Wolfgang Treue, Ritualmord und Hostienschändung, (unpublished MA thesis), quoted after Cluse, "Blut ist im Schuh," 376 (see note 23); Lotter, "Hostienfrevelvorwurf," 538 (see note 17). 
To avenge the crime the Jews, as an entity, had committed against the host, Christ, and Christianity as a whole, their death was the only imaginable punishment, which not only became an inevitable element of the narrative but was translated into reality in the form of persecutions of Jews that went farer and farer beyond the local scale. There was no longer any space left for repentant Jews who wished to join the ranks of the true faith, neither in the course of the narrative nor in the real world. Their role as surviving witnesses, as living proof of the sanctity of the host was no longer required. In the words of the third witness of Korneuburg, the dean Jacob, the mere fact that the bloodied host had been found in their, in Jewish, hands, was proof enough that it was a genuine, miracle-working host.

The Jews could, even should, be disposed of after they had fulfilled their role in the narrative; their killing had become integral to pilgrimage itself. ${ }^{66}$ They are the profaners, the perpetrators who force the host into (re-)action by bleeding, crying, turning into a piece of flesh or a child, or flying away, ${ }^{67}$ and are removed from the center of the story, killed at the end of the first act of the narrative. Zerkel, the scholar, and the other eight (or nine) Jews at Korneuburg are hardly even given a chance to witness the host's power and holiness. We do not know exactly how much time had elapsed between the moment the host was found on Zerkel's doorstep and the death of the Jews, but apart from its indestructibility, they do not get to see the miracles it works, thus they have no reason to convert.

Was there any room for doubt at all in the minds of the Christians, to question this seemingly fixed role of the Jews? Ambrose of Heiligenkreuz, the one who is most immediately concerned with the aftermath of the Korneuburg murders seems to be the most doubtful. ${ }^{68}$ In his treatise on the miraculous host, ${ }^{69}$ he elaborated on the somewhat difficult and trying circumstances under which he had to carry out the investigation. Not only the members of the commission seemed to have been at variance with each other, disputing over the catalogue of questions to present to the witnesses as well as the defining features of miracles,

66 Merback, The Thief, the Cross and the Wheel, 190 (see note 54).

67 Fabre-Vassas, The Singular Beast, 151-52 (see note 48). See for a variety of potential 'revealing acts' Heil, "Gottesfeinde" - "Menschenfeinde," 244 (see note 38).

68 About 100 years later, Jan Hus (then still officially orthodox), in his treatise De Sanguine Christi (1404), would condemn all bleeding hosts as fabrications of greedy priests (František Graus, "Fälschungen im Gewand der Frömmigkeit," Fälschungen im Mittelalter 5, 261-82; here 269-70, fn. 38 [see note 17]).

69 Library of the Monastery of Klosterneuburg, Codex 825, fol. 1v.-15v. For the relevant paragraphs, see Brugger and Wiedl, Regesten 1, 144-46, no. 135 (see note 1). The treatise was written about a year after the incidents, while the prologue was added around 1312, see Stelzer, "Am Beispiel Korneuburg," 332-33 (see note 12). 
but the citizens of Korneuburg protested vehemently against the continuing work of the commission.

Suspecting that the commission would forestall, or at least defer, the approval of their miracle-working host, an angry throng gathered in front of the house where the interrogations took place and tried to bar the witnesses from entering. Their wrath was primarily directed against Ambrose and Duke Rudolf III whom they accused of taking "the side of the Jews" - an interesting argument, considering that the main purpose of the commission was to find out whether the host had been consecrated and the miracles genuine, so there was no "side of the Jews" (who had been dead for two and a half months at this time) Ambrose and Rudolf could have possibly taken. Did they refer to any potential doubts regarding the guilt of the Jews and the legitimacy of the deaths the duke and the monk might have harbored or, if Ambrose rendered it correctly to begin with, was it a simple image meant to contrast them, the townspeople, with those who were not part of their community?

As with the commission, the focus of Ambrose's treatise lay mainly on the question of the authenticity of the host. Tellingly, as Winfried Stelzer has pointed out, Ambrose mostly used the word for the non-consecrated wafer (oblata) instead of the consecrated host (hostia), or labelled it hostia mirificata instead of hostia mirifica, ${ }^{70}$ yet he did not come to a final conclusion regarding its power to work miracles. Only in an addentum he revoked the advice he had given the Bishop of Passau to contact the pope in the question of how to handle the veneration of a potentially non-consecrated host. Upon reading of other host miracles, he was now convinced that the miracles alone that the host had worked were sufficient evidence to warrant its veneration. ${ }^{71}$

The same vagueness was applied to the question that is central for the topic at hand-whether the Jews had been rightly punished for their crime, whether the legitimacy of the procedure was questionable, or whether they had actually been wrongfully killed. While Ambrose shied away from making an irrevocable judgment, he concluded that the killing, or even the punishment of the Jews, did not seem justified to him. He argues that the citizens had acted precipitately, without closely scrutinizing what had really happened. His treatise not only reflects the idea of Christian mercy, but he also blames the citizens for not allowing the host to work its salvific purpose of showing the Jews the error of their ways. Ambrose is perhaps the one who reports another, otherwise unknown, accusation of host desecration against the Jews of Vienna that gives interesting insight into the role of the second target of civic critique: Duke Rudolf III. ${ }^{72}$ Interestingly, in

\footnotetext{
70 Stelzer, “Am Beispiel Korneuburg,” 336 (see note 12).

71 Stelzer, "Am Beispiel Korneuburg," 341 (see note 12).

72 Brugger and Wiedl, Regesten 1, 156-57, no. 147 (see note 1). On the question of authorship, see
} 
retelling the events, the author leaves no doubt about the question of the Jews' innocence. A peasant had stolen a host and thrown it into a jug that stood close to a Viennese Jew's house. When the host miraculously started to whimper from within its prison, people were soon gathered around the jug (the source speaks of 100,000 persons, which is obviously a stereotypical exaggeration) and very quickly identified the Jews (who hadn't even appeared in person yet) as the culprits who had to be punished for their (intended) crime. Only the immediate presence of Duke Rudolf III, who with personal effort placated the enraged masses, saved the lives of 'his beloved Jews' (suos judeos karissimos), causing the author to add a scathing remark on Rudolf's preferential treatment of the Jews, from whose usury he profited and as whose protector and benefactor he appeared (defensor [ . . ] et fautor eorum).

The focus of the author's critique is clearly the duke. In addition to profiting from the Jews' property and usury (participare lucris et usuris eorum), Rudolf demands heavy taxes and dues from them (tollendo exacciones et munera maxima ab eis). Not only does this narrative give an interesting introspection into the quite popular and widespread allusion of rulers being bribed by Jewish money in return for protection, ${ }^{73}$ but it clearly conveys another message too. For the population, the combined presence of Jews, even if they were not physically present, and a host wafer could only mean one thing - that the Jews were about to commit, or had already committed, a crime.

These harsh words, if noted down by Ambrose or copied later, were not the first directed at Duke Rudolf III and his preferential treatment of the Jews. Since the Jews were his direct subjects and thus belonged to his immediate treasure, any attack on them he considered an attack on himself. ${ }^{74}$ At Korneuburg, he merely supported the investigation, pushing (in contrast to the citizens' accusations) for a quick result and even sent the witnesses home when they angered him with their protesting. A year later, when a similar accusation of Jewish host desecration was raised at St. Pölten, a town that belonged to the bishop of Passau, ${ }^{75}$ he came down

Stelzer, "Am Beispiel Korneuburg," 329 (see note 12), who argues quite succinctly that the incident had not been noted down by Ambrose but had merely been copied into the manuscript as a further example of a host-related miracle.

73 The allegation that rulers would profit financially from preventing the persecution of Jews, be it through taxing the Jews or because of having been bribed by them, is quite a commonplace in ecclesiastical chronicles, see the examples quoted by Treue, "Schlechte und gute Christen," 110-12 (see note 17), Lotter, "Hostienfrevelvorwurf," 549 (see note 17), further Johannes Grabmayer, Zwischen Diesseits und Jenseits. Oberrheinische Chroniken als Quellen zur Kulturgeschichte des späten Mittelalters (Cologne, Weimar, and Vienna: Böhlau, 1999), 28-29, 242-43, 275.

74 For an overview of the legal standing of the Austrian Jewry with regard to the Austrian duke, see Brugger, "Von der Ansiedlung," 134-51 (see note 12).

75 The bishop of Passau was the ecclesiastical overlord over the duchy of Austria that lay within the diocese of Passau, yet as far as the town of St. Pölten herself is concerned, the bishop was also the 
heavily on the citizens, fining them with 3500 pounds for the crime of killing his Jews. ${ }^{76}$ In the same year, he successfully quelled a persecution of the Jews of Vienna after another accusation of a host desecration had been raised there (see below).

Another crucial detail is revealed in Ambrose's treatise. Prior to the extensive investigation led by Ambrose, another inquiry of the whole incident had been carried out by Bishop Rudger, the abbot of the Scottish abbey in Vienna (Schottenstift), and the provost of the monastery of Klosterneuburg. Unfortunately, it is not possible with absolute certainty to place the two inquiries in chronological order. Ambrose labelled the one that was held upon the duke's instigation as the "first interrogation of witnesses," but based his arguments on facts that he learned later.

During this investigation, which had been commissioned by Duke Rudolf III, Zerkel's immediate neighbors had been interrogated, and their testimonies are more consistent (albeit only rendered in Ambrose's rather short summary) than the later, contradictory statements. ${ }^{77}$ Around the first hour of the day in question, three Jews dashed out of Zerkel's house, screaming and running after a Christian whom they accused of having thrown a host wafer into their house. They begged the bystanders to aid them in catching the culprit, who, they shouted, should rather burn than them (melius esset quod ipse comburetur quam nos). Since they were not able to catch him, the Jews returned to their house where the Christians, who in the meantime had gathered there, saw part of a bloodied host, covered by a piece of cloth, in the hand of one of the Jews. In these testimonies, stripped of all allusions to a prior purchase, failed attempts to dispose of the wafer, and of heavenly voices and guided feet, we can most likely recognize the bare facts around which the tale was later woven. The basics - the doorstep of the Jews' house, the Jews running through the town, the accusations towards the Christian, the gathering masses who discover the bloodstained wafer-remained the same, yet in the extensive investigation these facts were presented with a plethora of additional details that emphasized the miracle-working character of the host. These details completely altered the initial situation by introducing the postulate that the Jews had already been in possession of the wafer-meaning, had already executed their vile plans - long before the Christians had come to know of it.

The piece of information Ambrose put before his brief rendition of the first inquiry is central, and might have motivated him to re-write several passages of

secular lord of the town. This was not an unusual situation in the Middle Ages; see Norman Roth, "Bishops and Jews in the Middle Ages," The Catholic Historical Review 80 (1994): 1-17. 
his treatise. ${ }^{78}$ The bishop of Passau, Wernhard of Prambach, had informed him that a priest had confessed that he had instigated the whole incident at Korneuburg. ${ }^{79}$ By taking a simple oblate, dipping it into goat's blood and depositing it in front of the Jew's house to set up a reason for the defamation (quod accepisset oblatam simplicem et intinxit sanguine hyrcino et immisit causam calu[m]pnie ad domum iudei), he had created the prerequisite of not only the persecution of the Jews but also of what had, presumably, been his goal - to establish a pilgrimage site.

Together with four accomplices (consociis), he was willing to attest to this. Although this critical piece of information is put right before the summary of the first investigation, it is doubtful that either Ambrose, the Viennese Abbot, or any of the other members of the commissions had any knowledge of this prior to conducting the inquiries. In neither of the two investigations, regardless of which came first, was there any mention of a fraudulent priest, even if the possibility that the Jews might have been framed was very tentatively hinted at.

The real perpetrators can therefore be identified as follows: a priest and four accomplices who obviously were in cahoots in the scheme. No names are mentioned, but does it seem too speculative a guess to suspect Konrad, the vicar of Leobersdorf, as the main culprit? In his testimony before the commission, Konrad speaks of a 'repentant Christian' whom he had allegedly shriven, and who had confessed to having sold the wafer to the Jews, which had (further) sealed the belief in the Jews' guilt. In the light of the later findings, it is clear that his statement had to be a blatant lie.

The fact that a host had indeed been planted not only lends credibility to some of the testimonies-people had actually seen Zerkel and the scholar running through the town with a bloodstained host in their hands - but it also substantiates the statement of the terrified Jews that 'an evil Christian' had thrown the wafer onto their doorstep. It is, however, unlikely that the Jews were the fraudulent priest's primary target. Already the first alleged host wafer desecration in what is today Austrian territory, the events in Laa an der Thaya in 1294, had resulted not

Stelzer, "Am Beispiel Korneuburg," 338-39 (see note 12), argues that the first rendition of the treatise was written in late 1306 while the additions were worked into it around 1311, with the prologue being the last piece added in 1312.

The forging of "miracle-working" host wafers was not uncommon; the papal letter to bishop Albrecht II of Passau speaks of 'incidents similar to Korneuburg' that had taken place at Weikersdorf, while his letter to Duke Albrecht II of Austria mentions Linz (Brugger and Wiedl, Regesten 1, 339-40, nos. 442 and 443 [see note 1]), yet for neither of these two towns, is there any further documentation of a host desecration and an ensuing pogrom. See for German examples Lotter, "Hostienfrevelvorwurf," 574-81 (see note 17) (with Korneuburg as the main example); Graus, "Fälschungen im Gewand der Frömmigkeit," 268-70 (see note 68), again with Korneuburg (which he mistakes for Pulkau) and the forged host wafer of Wilsnack (that does not include accusations against Jews). 
only in the Jews being persecuted but also a chapel being erected on the spot where the 'body of the Lord' had been found. ${ }^{80}$

A miraculous host provided the parish where it was kept with prestige and posed a strong attraction for pilgrims. It is therefore quite logical to assume that it was the priest's main goal to establish a pilgrimage site that would increase both the reputation and the revenues of the parish. To achieve this goal it would not have been enough merely to launch a story about a miraculous host; he needed the wafer itself as a tangible element. In putting all the key elements together - a host wafer, blood, and Jews - the fraudulent priest provided a scenario that allowed Christians to indulge fully their fantasies about the mistreatment and murder of Christ by the Jews.

The killing of the Jews might have been a spur-of-the-moment action, ignited by ubiquitous anti-Jewish sentiment and the desire for revenge, yet when they accused Ambrose and Rudolf III of hampering the investigation, they seemed to have been aware of the material benefits they could gain from an established and approved miraculous host. Pilgrimage hotspots, in turn, prolonged and nourished the Christian ideas of Jews maltreating hosts. Those who visited the site no longer only heard a tale but actually saw the maltreated host, the tangible (or at least visible) proof that Jewish host desecration was indeed a reality. Illustrations such as the (later) altar paintings at Korneuburg further helped the pilgrims to visualize the crime of the Jews, and thus they were bound to feel that the guilty Jews deserved their fate. ${ }^{81}$

It must remain pure speculation to include those witnesses who give the most detailed information as being in cahoots with the priest. Even if we identify the unnamed priest as Konrad of Leobendorf, there is no evidence that the four others he named as his accomplices were interrogated at all. Furthermore, with the intervention of Duke Rudolf III, who wanted the investigation brought to a quick end, there is a notable change in the procedure. The interviews became shorter and shorter, and although the witnesses were presented the full catalogue of questions, they were not encouraged to elaborate. These source-related considerations notwithstanding, some of the witnesses stand out with respect to the details they reveal. Konrad an der Hochstrass not only verified the vicar's testimony on the purchase of the host, but heaped additional blame on the Jews by shifting the confession from the vicar's unnamed layperson to the Jewish scholar. More details, such as the name of the Christian the Jews tried to persuade to dispose of the host

Brugger and Wiedl, Regesten 1, 89-90, no. 82 (see note 1). On the general 'restoration of the order,' the transformation of Jewish houses or synagogues into chapels (that usually housed the maltreated host), see Rubin, Gentile Tales, 89-91 (see note 3).

81 Merback, The Thief, the Cross and the Wheel, 195 (see note 54), also on the visual presentation of the host wafers. 
for them, including the exact wording of this Christian's outburst when confronted with the host, were reported by Konrad an der Hochstrass, albeit, as he claimed, only by him rendering the dying scholar's last words.

Equally suspicious are Otto an dem Roßmarkt, who had the scholar say that the Jews fully deserved their fate for their misdeeds, and, the baker Sifridus (Sidlin) and his heavenly-guided feet. The latter also provided the reason why the host was deposited at Zerkel's doorstep: after seeing the host lying on the floor and standing mesmerized, Sifridus himself put it there when he saw the blood oozing from it. It must, as with the other witnesses, remain pure speculation whether Sifridus was in cahoots with the priest, yet there is much evidence that he, in fact, had been the one to whom the priest had assigned the task of planting the host wafer. First and foremost, as Miri Rubin pointed out, he had the crucial requisite at hand - the wafer itself, which is basically nothing but a piece of baked dough. ${ }^{82}$

Furthermore, his spectacular story of heavenly guidance, the picking up of the host at first and then putting it down again might have served as an explanation should he be caught red-handed. Sifridus himself confirmed that his finger had remained bloodied after he had put the host down. It must, again, remain pure speculation as to whether Sidlin's testimony had been agreed upon beforehand, and if so, to what purpose. It is possible that they sought to introduce the element of the heavenly intervention, to which the priest was hoping the theologically (more or less) versed interrogators would find appealing.

All of this, however, suggests not only Sifridus's involvement, but also points towards a scheme that was not a spur-of-the-moment act, but a premeditated plot that required meticulous planning. Only one other witness, Bertha, the wife of Konrad Reus, confirmed that she had seen him with the host but other than that merely stated that she 'concurs with him in regard of how the host was found.' Other witnesses only name Sidlin as being among those present at the retrieval of the host without crediting him with any special task. The Christian whom the Jews accused of having thrown the host into their house-who, according to his testimony, would have been Sidlin himself-remained anonymous in all other versions.

Most of the witnesses remained extremely vague about actual healings. When asked about specific names and time, the priest Friedrich responded quod solum ex fama hec scit. The second priest that was interrogated, Hertricus, responded in a quite similar manner: quod nichil scit de hoc nisi per auditum et famam. Otto an dem Roßmarkt, eager to share information, gave suspiciously elaborate details on the miraculous work of the host. He gave details about the cures of the 
aforementioned Bohemian girl plagued by demons and of the paralyzed Viennese woman. The former had been suffering for thirteen years and the latter for eight years, four of which had been spent in a hospital in Vienna. Yet, despite his indepth knowledge, he could not specify the precise day or hour of their healing.

The miraculous healing that was brought up the most was that of the local weaver, Pero. Altogether ten witnesses claim that they knew about his healing, although most of them again resorting to hearsay. Only Otto an dem Roßmarkt explicitly admitted to actually having been present when Pero was healed. According to him, Rapoto Tasch (the eleventh witness) and Konrad Klett had been there too, et pluribus aliis. ${ }^{83}$ Despite the fact that Pero was "known to everyone in the town," as Otto claimed, his fellow citizens were not able to give any precise details on the amount of time he had spent in his paralysed state, which differed between two and five years in the witnesses's statements.

To suspect that Pero might have been in cahoots with the fraudulent priest by faking a 'spiritual healing' might go too far, since he was not the first but only the most known of the lucky ones through whom the host demonstrated its power. It is surprising that he was not among the witnesses despite the fact that he still lived in Korneuburg, particularly since the commission was more concerned with the miracles (and their genuineness) than with the Jews' fate.

Judging by the list of those that had been miraculously cured within the first months of the host's work, the fame of the site had expanded quite quickly, thus allowing us to speculate that the priest's goal was achieved even if there is no mention of a pilgrimage site in the decades following the incident. Only two papal letters from the year 1338 that investigated the Pulkau persecutions in Lower Austria give insight into the continuing veneration of the Korneuburg host. What had happened in the meantime reads like a reflection of the earlier incidents. Since the original wafer had been eaten away by moths and worms but was still being venerated by the faithful masses, a misled priest (suggestione diabolica persuasus errorem errori accumulans) had taken a new, non-consecrated wafer, dipped it in blood and supplanted the old one, presumably not to impede the flourishing of the pilgrimage site. ${ }^{84}$

Due to the increasing brevity of the interviews, many of the witnesses merely respond that they 'concur with what the others stated,' which makes it impossible to decide whether they meant that they were present or had just heard about it both of which had already been stated by others. Rapoto Tasch for example (the nineteenth witness), who was reported by Otto an dem Roßmarkt as having been present, merely declares that he corroborates what the others had said; only the eleventh witness, the alderman Marquard, explicitly states that he had not been present when Pero had been healed.

Odericus Raynaldus and Jacobus de Laderchius, Annales ecclesiastici denuo excusi et ad nostra usque tempora perducti ab Augustino Theiner, 25: 1334-1355 (Bar-le-Duc: Ludovicus Guerin et socii, 1872), 118-19. To 'support' a host wafer that was being venerated yet had possibly not been consecrated 
In the same year 1338, the Dukes Otto II and Albrecht II gave the Augustinian order a plot of land at Korneuburg that had once belonged to their Jews (aream olim nostrorum judeorum [...] intra muros in Neunburch) ${ }^{85}$ and granted them the right to erect a monastery there - which also meant that the (former) presence of the Jews and their crimes stayed in the collective memory of the Christian community. ${ }^{86}$ According to local tradition that was still (again?) alive in the $1960 \mathrm{~s}^{87}$ this was the spot where Zerkel's house had once stood-a somewhat believable tradition actually, since it is highly likely that Zerkel's house was the only "Jewish" house in Korneuburg. ${ }^{88}$

With the actual culprit being known to the authorities, the question arises whether he had been punished for his offence. Ambrose in his treatise strongly recommended it, and even declared that the priest alone, and not the Jews, should have borne the consequences and the wording of the papal letter suggests that the felonious priest had indeed not emerged unscathed. Yet the sources are too scarce to track down any details on his potential punishment. ${ }^{89}$ What can be gathered however are two things: the idea that a priest would misuse the tales of host desecration to his advantage was not unthinkable to either pope, bishop, or duke, and that, in order to make the scheme work, any fraudulent cleric (or layperson) could safely rely on the concept of the default guilt of the Jews which was firmly ingrained in the common mind-set. ${ }^{90}$ The host, as the Korneuburg dean Jacob stated, had been found at the Jews' place, and that alone served as sufficient proof for its authenticity.

with a consecrated one is however not unusual: when the same problem arose at Pulkau in 1338, where a bloodied host had been found under rather similar circumstances (in front of a Jew's house, on the street, covered with straw) and was being worshipped at the parish church, the Bishop of Passau had a consecrated host put next to it; Chronicle of Francis of Prague (Chronicon Aulae Regiae) from the year 1338, see Brugger and Wiedl, Regesten 1, 347, no. 453 (see note 1). Haus-, Hof- und Staatsarchiv (Austrian State Archives), Vienna, AUR 1338 XI 19 (Brugger and Wiedl, Regesten 1, 343, no. 447 [see note 1]).

86 See Zeissl, Das ehemalige Augustinerkloster (see note 33).

87 Germania Judaica, vol. II: Von 1238 bis zur Mitte des 14. Jahrhunderts, part 1: Aachen - Luzern, ed. Zvi Avneri (Tübingen: J.C.B. Mohr, 1968), 450.

88 The medieval synagogue in Korneuburg was erected in the fourteenth century, but the (sometimes quoted) time span of 1305 to 1325 for its construction seems highly unlikely, since there is no mention of a Jewish presence in Korneuburg up until 1378 (Germania Judaica II/1, 450 [see note 87]).

89 If we go with the assumption that it was Konrad, the vicar of Leobendorf, the sources remain silent on him: the Urkundenbuch des Stiftes Klosterneuburg bis zum Ende des vierzehnten Jahrhunderts (see note 30) does not mention a Konrad, vicar of Leobendorf.

90 Wolfgang Treue gives examples of Christians who, obviously firmly believing in the Jewish need for consecrated host wafers, tried to make money off this by trying to sell them hosts (and, occasionally, children), which the Jews refused (and sometimes sued them for it); Treue, "Schlechte und gute Christen," 104-06 (see note 17). 
The fact that a fraudulent priest had staged the host desecration and brought about the consequences suffered by the Jewish population remained known to both secular and ecclesiastical authorities. In August 1338, Pope Benedict XII commanded the bishop of Passau, Albrecht II of Saxony-Wittenberg, to investigate a wave of anti-Jewish riots that had resulted from alleged host desecrations in the Lower Austrian towns of Pulkau and Weikersdorf, and the Upper Austrian town of Linz. ${ }^{91}$ The investigation had been requested by the Austrian Duke Albrecht II, the brother and successor of the late Rudolf III, who had urged the Apostolic See to find out whether Jews had been guilty of the crime or had been innocent as had been the case at Korneuburg, phrasing his suspicions of foul play in no uncertain terms.

In fact, the two letters by Benedict XII are, apart from Ambrose's treatise, the only sources that mention the priest's criminal deed and thus provide information on the real course of events at Korneuburg. ${ }^{92}$ The alleged host desecration at Pulkau ( $80 \mathrm{~km} / 50 \mathrm{mi}$ northeast of Vienna) had triggered the first wave of persecution in Austria that went beyond the local scope. Apart from the Jewish population of Pulkau, the Jews of many small towns in the surrounding area fell prey to the frenzied mob. ${ }^{93}$ The Nürnberg memorial book lists 31 "blood sites" in

For Weikersdorf (west of Wiener Neustadt) and Linz, neither an accusation of host desecration nor a persecution of Jews is documented elsewhere; the Nürnberger Memorbuch ("memorial book"), the list of the 'blood sites' (Blutstädte), the sites of Jewish persecutions, cites neither Weikersdorf nor Linz; Siegmund Salfeld, Das Martyrologium des Nürnberger Memorbuches. Quellen zur Geschichte der Juden in Deutschland, 3 (Berlin: Leonhard Simion Verlag, 1898), 68 (Hebrew) and 420-21 (German); see also Brugger and Wiedl, Regesten 1, 348-49, no. 455 (see note 1), on memorial books in general, see Aubrey Pomerance, "'Bekannt in den Toren:' Name und Nachruf in Memorbüchern," Erinnerung als Gegenwart: Jü̈dische Gedenkkulturen, ed. Sabine Hödl and Eleonore Lappin (Berlin and Vienna: Philo, 2000), 33-54. Alfons Žák, "Zur Kirchengeschichte Niederösterreichs," Monatsblatt des Vereins für Landeskunde und Heimatschutz von Niederösterreich und Wien, 12.1/1 (1926/27), 6-7 suspects the Lower Austrian town Retz, close to the Bohemian border and listed in the memorial book of Nürnberg, behind the seriously misspelled name of Linz (Fyncz, Syntz). To include the Pulkau persecutions into the wave of persecutions that had sprung up around the same time in the Bavarian town of Deggendorf and had spread quickly throughout the southern regions of the Holy Roman Empire is somewhat problematic for the lack of any immediate connection; although some of the mainly ecclesiastical sources either mix up these two events or merely report of 'Jews being killed in the southern parts'.

92 Editions: Shlomo Simonsohn, The Apostolic See and the Jews, vol. 1: Documents 492-1404. Pontifical Institute of Medieval Studies, Studies and Texts, 94 (Toronto: Pontifical Institute of Medieval Studies/Brepols, 1988), 371-74, nos. 354-55 (full text of the letter to the bishop of Passau, summary of the letter to Duke Albrecht), and Raynaldus and de Laderchius, Annales ecclesiastici, 118-19, nos. 20-21 (full text of the letter to Duke Albrecht, summary of the letter to the bishop).

Rubin, Gentile Tales, 65 and 68 (see note 3), gives the number of '150 Jews of Pulkau' that were killed during the persecutions, which is by far too high a number for a small Lower Austrian town. Her assessment that it was Duke Otto's 'abandonment' of the Austrian duchy in favour of the 'recently annexed' Styria (which was neither 'annexed' nor recently acquired by the Habsburgs) that made the Pulkau persecutions possible ignores the existence of Otto's brother, 
Austrian, Moravian, Bohemian, and Bavarian territory. ${ }^{94}$ The incident that had started the Pulkau persecutions reads quite similar to what had happened at Korneuburg (and many others in the centuries to come), containing all the key elements of the classical narrative: a blood-stained host was found in front of a Jew's house, ${ }^{95}$ and, incited by what the Jews had undoubtedly done to it, the Christian population sought revenge.

Unfortunately, the outcome (if there was any) of bishop Albrecht's investigation is not documented. Duke Albrecht II, however, proceeded to follow the policy of his older brother Rudolf III in prosecuting anti-Jewish outbreaks. During the period of the Black Plague, that saw the violent end of many Jewish communities in the Holy Roman Empire, Albrecht managed to a large extent to maintain the safety of the Austrian Jewry. ${ }^{96}$ Albrecht II did not shy away from resorting to drastic measures when the Jews - and thus a part of his treasury - were attacked. The only persecution of Jews during this time in Austria, in the town of Krems that housed the second-largest Jewish community in Lower Austria, was met not only with heavy fines but the leaders of riot, who were among the most important

Duke Albrecht II (whom she mistakes for Albrecht II of Saxony, the bishop of Passau).

Some of the listed names, such as Passau (Bavaria) are in today's academic literature counted as part of the Deggendorf persecutions (see Germania Judaica, vol. II: Von 1238 bis zur Mitte des 14. Jahrhunderts, part 2: Maastricht-Zwolle, ed. Zvi Avneri [Tübingen: J.C.B. Mohr, 1968], 647-48, fn. 7), whereas for the Carinthian town of Villach, which is geographically the most remote from the centre of the violent outbreaks, a persecution of the Jews is not documented in any other source; Jewish presence in Villach is after 1338 first documented for the year 1346 (Eveline Brugger and Birgit Wiedl, Regesten zur Geschichte der Juden in Österreich im Mittelalter, vol. 2: 1339-1365 [Innsbruck, Vienna, and Bolzano: StudienVerlag, 2010], 62-62, no. 570 (for the internet version, see http://www.injoest.ac.at/projekte/laufend/mittelalterliche_judenurkunden/; last accessed on March 10, 2012).

A Jew Merchlin at Pulkau is documented for the year 1329, when he purchases a plot of land from a local nobleman (Brugger and Wiedl, Regesten 1, 257-58, no. 303 [see note 1]); it is highly likely that he is identical with the Marquardus iudeus in front of whose house the host was found in 1338 (on the equation of Merchlin and Marquart, both derivations of Mordechai, see Alexander Beider, A Dictionary of Ashkenazic Given Names. Their Origins, Structure, Pronunciation, and Migrations [Bergenfield, NJ: Avotaynu, 2001], 375-76, 382). For an overview over the Pulkau-related sources, see Brugger and Wiedl, Regesten 1), 333-35, nos. 434-36, 339-41, nos. 442-43, 343-51, nos. 448-56 (see note 1); for an overview of the events, see Brugger, "Von der Ansiedlung," 216-19 (see note 12); Manfred Anselgruber and Herbert Puschnik, Dies trug sich zu anno 1338. Pulkau zur Zeit der Glaubenswirren (Pulkau: Verlag der Gemeinde, 1992); Rubin, Gentile Tales, 65-68 (see note 3); Birgit Wiedl, "Die angebliche Hostienschändung in Pulkau 1338 und ihre Rezeption in der christlichen und jüdischen Geschichtsschreibung," medaon. Magazin für jüdisches Leben in Forschung und Bildung 6 (2010), internet journal, see http://medaon.de/pdf/A_Wiedl-6-2010.pdf, last accessed on March $10,2012$.

96 It is against the backdrop of the many massacres in the German-speaking area that Joseph haCohen's description of Austria as a 'safe haven' in his Emek habacha becomes understandable, Joseph haCohen, Emek habacha. Transl. from the Hebrew into German by M. Wiener (Leipzig: Oskar Leiner, 1859), 54. 
citizens, were beheaded. ${ }^{97}$ These drastic actions, in turn, earned him the title of fautor iudeorum, "benefactor of the Jews," from the clerical chroniclers, ${ }^{98}$ subjecting him to the same critique as his brother Rudolf III as well as their father, King Albrecht I, and grandfather, King Rudolf I. ${ }^{99}$

There is no documentation in either Laa an der Thaya or in Korneuburg or Pulkau of anti-Jewish outbreaks before the fateful accusations. A tax regulation of 1277 for the town of Laa that incorporated the tax the Jews had to pay into the general city tax (in unserr burger dinst) suggests a rather peaceful cohabitation enjoyed by Christians and Jews in these small towns. ${ }^{100}$ While the tax regulation of Laa and the Korneuburg persecution were the first traces of Jews dwelling in these town respectively, ${ }^{101}$ we have scarce evidence of Jewish life in Pulkau before the 1338 catastrophe, yet for neither of these towns (and most of the other towns that were afflicted by the Pulkau persecution), a continuance, or reestablishment, of Jewish settlement is documented.

Klaus Lohrmann has suggested that after the Pulkau persecutions, Jewish life tended to focus on the major cities, such as Vienna, that housed bigger Jewish communities which could, if need arose, provide better shelter. ${ }^{102}$ Although the

Brugger and Wiedl, Regesten 2, 95-98, nos. 645 and 647 (for Plague-related pogroms in Austria, see generally nos. 645-51) (see note 94).

Kalendarium Zwetlense, see Brugger and Wiedl, Regesten 2, 98, no. 647 (see note 94).

Ecclesiastical chronicles continually lambasted the early Habsburgs for their King Rudolf I had been criticized heavily for his intervention in the veneration of Werner of Oberwesel in 1288 ("Chronicon Colmariense," Monumenta Germaniae Historica, Scriptores, vol. 17, ed. Georg Heinrich Pertz [Hanover: Hahnsche Buchhandlung, 1861], 240-70; here 255) while Albrecht I's favorism of the Jews resulted not only in his son's Rudolf III's untimely death but also his own violent murder at the hands of his nephew ("Continuatio Zwetlensis Tertia ad a. 1294," ed. Wilhelm Wattenbach. Monumenta Germaniae Historica, Scriptores, vol. 9, ed. Georg Heinrich Pertz [Hanover: Hahnsche Buchhandlung 1851, rpt. Stuttgart: Anton Hiersemann Verlag, 1983], 654-69; here 663. For the internet version of the MGH volumes, see www.dmgh.de, last accessed on March 10, 2012). See further Eveline Brugger, “Minem herren dem hertzogen sein juden': Die Beziehung der Habsburger zu 'ihren' Juden im Österreich des 14. Jahrhunderts," Tagungsbericht des 25. Österreichischen Historikertags, St. Pölten 2008, ed. Verband Österreichischer Historiker and Niederösterreichisches Landesarchiv (St. Pölten: Verlag des Landes Niederösterreich, 2010), 742-49; here 746-47.

Germania Judaica III/1, 674 (Korneuburg) and 697-98 (Laa) (see note 13). In Laa, a Jew Herzlein is mentioned in the year 1378 (HHStA, AUR 1378 V 14).

Klaus Lohrmann, Judenrecht und Judenpolitik im mittelalterlichen Österreich (Vienna and Cologne: Böhlau, 1990), 155. A similar development can be detected in other parts of the Holy Roman Empire where the Jewish communities of both urban and rural settlements were hit hard by Plague-related pogroms: the re-settlement took place mainly in the urban centres, see Rainer Barzen, "Benei haKefarim - die Leute aus den Dörfern. Zur jüdischen Siedlung auf dem Lande in Aschkenas und Zarfat im hohen und späteren Mittelalter," Campana pulsante convocati. Festschrift anläßlich der Emeritierung von Prof. Dr. Alfred Haverkamp, eds. Frank G. Hirschmann and Gerd Mentgen (Trier: Kliomedia, 2005), 21-37; here 27. See also Birgit Wiedl, "'Lazarus and Abraham, 
number of Jewish rural settlements should not be underestimated, the assumption that bigger communities could provide better protection holds true for Austria, at least during the thirteenth and fourteenth centuries. For example, the accusations of having committed a ritual murder against the Jews of Krems in 1293 that resulted in the execution of two Jews did not hamper the flourishing of the secondlargest Jewish community in the duchy; ${ }^{103}$ and neither did the Plague-related accusations of well-poisoning levied against the Jews of Krems in 1349 have any distinct impact on the well-established standing of the Jewish community. ${ }^{104}$

However, even the largest and most prosperous of all Austrian communities, the Jewish community of Vienna, was completely defenseless when, at the beginning of the fifteenth century, the ducal protection, that had seriously waned during the last decades of the preceding century, turned into oppression. The catastrophe that befell the Jewish community of Vienna in the years 1420/21, the incarceration, explusion, forced conversions, and, eventually, burning of more than 200 Jews, differed essentially from the earlier persecutions that had erupted spontaneously. The Vienna Gesera, the brutal and ruthless annihilation of the Viennese, and, in succession, the Austrian Jewry, had been meticulously planned and carried out by Duke Albrecht V (the later King Albrecht II). ${ }^{105}$ Whereas the manifold motives for

our Jews of Eggenburg': Jews in the Austrian Countryside in the Fourteenth Century," Rural Space in the Middle Ages and Early Modern Age: The Spacial Turn in Premodern Studies, ed. Albrecht Classen, with the collaboration of Christopher R. Clason. Fundamentals of Medieval and Early Modern Culture, 9 (Berlin and New York: De Gruyter, 2012), 639-71; here 659-60.

The two chronicles that refer to the incident are quite vague on this - the Continuatio Vindobonensis only mention that Jews had killed a Christian, without any further comment on their fate (Iudei in Crems occiderunt christianum), while the Continuatio Zwetlensis Tertia, albeit clearly implying a ritualistic motiv, mostly utilizes the incident to scold the Austrian Duke Albrecht I for his 'favouring the Jews.' The way of the Jews' execution (broken on the wheel) suggests a formal verdict (Brugger and Wiedl, Regesten 1, 87-88, nos. 78-79 [see note 1]; for executions of Jews, see Ernst Schubert, Räuber, Henker, arme Sünder: Verbrechen und Strafe im Mittelalter [Darmstadt: Wissenschaftliche Buchgesellschaft, 2007], 61-64).

Brugger and Wiedl, Regesten 2, 97-99, nos. 646-47, 649 (see note 94). A iudex iudeorum (Judenrichter, 'judge for the Jews'), a Christian who was responsible for Jewish-Christian disputes and business transactions, whose existence is usually a signifier for a larger, and considerably important, Jewish community, is documented quite continually; in 1355, the first Jew is mentioned again when the Jewess Czaetel, widow after Mosche of Krems, sells her house in Krems. See idem, 163, no. 790, and generally Hannelore Hruschka, Die Geschichte der Juden in Krems von den Anfängen bis 1938. 2 Vols. (Vienna: University of Vienna, unpublished dissertation, 1978).

The only extensive publication on the topic is still Samuel Krauss, Die Wiener Geserah vom Jahre 1421 (Vienna and Leipzig: Wilhelm Braumüller, 1920). An edition of the text of the "Wiener Gesera," the German-Yiddish report of the incident, and Albrecht's two verdicts, by Artur Goldmann, Das Judenbuch der Scheffstrasse zu Wien (1389-1420). (Vienna and Leipzig: Wilhem Braumüller, 1908), 112-33 (appendix); see also the newer discussions by Klaus Lohrmann, Die Wiener Juden im Mittelalter (Berlin and Vienna: Philo, 2000), 155-73, Judenrecht und Judenpolitik, 298-309 (see note 101); Brugger, "Von der Ansiedlung," 221-54 (see note 12); and Rubin, Gentile Tales, 116-19 (see note 3), with a discussion of the Jewish-Hussite connection (or the lack thereof). 
this violent destruction of the Austrian Jewry - a suspected collaboration with the Hussites, the ducal lust for the treasures they had allegedly hidden-and the extent to which the university of Vienna and its anti-Jewish preachers exerted their influence are still discussed, one key element ties in with what had happened more than a century earlier in the small town of Korneuburg. When severely reprimanded for his actions by Pope Martin V, ${ }^{106}$ Albrecht V excused his actions with what he knew to be a safe bet. In his verdicts, Albrecht declared that a female sacristian (mesnerin) of the Upper Austrian town of Enns had sold a consecrated host several years before to the Jews who intended to desecrate it. Furthermore, the Jews had passed the host among themselves throughout the duchy and abroad, thus implicating more Jews in the crime and adding conspiracy to deicide and profanity.

Since Albrecht's declaration was made only after the Jews were killed, we must take this fact into account when discussing it. Despite the popularity of the tale, there had been no rumors of an accusation of Jewish host desecration at Enns before Albrecht V's verdicts, and interestingly, neither was it taken up by the clerical chroniclers who reported the incidents, nor did a pilgrimage site develop out of it. It is highly plausible that Albrecht utilized a prevalent and wellestablished pattern to explain and legitimate his actions. Albrecht could safely rely on the default crime scenario that provided all the elements that were crucial to establish the Jews' guilt. It had worked a few years earlier in the archbishopric of Salzburg where the Jews had been made to confess to both host desecrations and ritual murder under torture before they were either killed or expulsed, ${ }^{107}$ and it would work numerous times in the fifteenth century, in Breslau (1453), in Passau (1477) and Sternberg (1492), to name but a few, ${ }^{108}$ and would remain one of the central fantasies Christians indulged in when contemplating Jewish crime, even if they, in the retrospect of later centuries, would either not fully understand the earlier concept and/or add their own ideas.

At Korneuburg, like in many other towns that hosted a church with a miraculous host (often named 'Church of the Holy Blood'), the centuries to follow did not consider the Jews' possible, or proven, innocence, but added new aspects of the Jews' misdeeds that catered to these centuries' own ideas and readings of the story. The image of Jews desecrating a host by throwing it into a well, a motif

Goldmann, Judenbuch, 120-21 (see note 103), the mention of the papal intervention in the text of the Gesera 130.

Markus Wenninger, "Die Entwicklung der Stadt Salzburg-zur Geschichte der Juden in Salzburg," Geschichte Salzburgs Stadt und Land. Vol. 1/2: Mittelalter, ed. Heinz Dopsch and Hans Spatzenegger (Salzburg: Pustet, 1983), 747-56.

For further examples, see Lotter, "Hostienfrevelvorwurf," 578-81 (see note 17); Rubin, Gentile Tales, 119-31, with other examples throughout chapter 6 (including Passau and Sternberg) (see note 3 ). 
that appears frequently in the later host desecration tales, is found at Korneuburg not in the medieval tale but is only introduced in a cycle of eleven (originally twelve) paintings from 1660 (see Figs. 2-12) that rendered not so much the original incident but this century's idea of it. ${ }^{109}$ The creation of this cycle of paintings, that was displayed in the monastery's cloister and had been donated by aldermen, the parish priest, and high-ranking citizens of Korneuburg, coincided with the copying of the protocols in the year $1655^{110}$ that was presumably manufactured on the occasion of the (alleged) retrieval of an almost-saintly object-not the host itself, but the piece of cloth that had once covered the miraculous host. ${ }^{111}$

Again, heavenly intervention had guided the steps of a citizen, the alderman Johann Georg Neckinger (also Reckinger), and had assisted him in finding "the cloth which the most holy host had been wrapped in and hidden in the local parish church for innumerable years" (das tuechl darin die allerheilig hostia eingewikelt und unerdenkliche jahr in der alhieigen pfarr kirchen verborgen war). Around the same time, a 'book of miracles' (Mirakelbuch) was published by the monastery that retold the story of the miraculous host. In its account, the miracle book left no doubt as to who was to be considered the main perpetrator, and, like the cycle of panels, included the motif of the host being thrown into a well. The general revival of the legend of the miraculous host and the pilgrimage site connected with it were in answer to the precarious situation the monastery found itself in in the middle of the seventeenth century. Re-established in 1624, the monastery had suffered damages from several fires and the Swedish siege in 1645/56.

The temporal coincidence of this revival is striking. Only three years earlier, in 1652, new panels had been added to the main altar of the parish church at Pulkau that illustrated the local miracle-working host wafer, and had successfully provided a popular attraction for both locals and pilgrims. The legend had prevailed in Korneuburg over the centuries, but had suffered a decline in importance. An earlier illustration, from around 1470, can be found on a small portable altar (Klappaltar) the centrepiece of which had served as a repository for the blood-stained cloth (see Fig. 1). On the two side wings, four paintings show the Jewish scholar (upper right, already with the infamous yellow circle on his cloak) holding the host and the bloodied cloth in his hand, and three of the wonders that

Graus, Pest, Geissler, Judenmorde, 299-340 (see note 11), on the emergence of the myth of Jewish well-poisoning in the fourteenth century; Rohrbacher and Schmidt, Judenbilder, 194-202, for an overview of the later development (see note 8). 
the host had worked - the healing of two blind (lower left) and two handicapped (lower right), and the lighting of candles (upper left). ${ }^{112}$

Although the painting does not actually show the Jew maltreating the host, the implication is again clear: a Jew holding a host in his hands means desecration. In the centuries to come, the seventeenth-century paintings reflected the peoples' ideas about the course of events and that would influence future perceptions of them, particularly since copper engravings of them were included in the later editions of the miracle book.

The late nineteenth and the mid-twentieth century left no doubt as to who was to be regarded as the culprit(s). ${ }^{113}$ An amalgam of the late-medieval events and the early modern additions, the tale bears only slight resemblance to what the witnesses, convinced of the Jews' guilt or not, had testified 600 years ago: after buying the host from a criminal and/or foolish Christian and doing unspeakable things to it, the Jews threw the maltreated host into a well but retrieved it again since it drew attention by shining brightly from within the water. They then bribed a dim-witted Christian servant to get rid of it for them, and when he refused, they ran after him, accusing him of having thrown the host into their house. The Jewish scholar showed the host wafer, from which blood was seeping so that it soaked the cloth it was wrapped in, to the gathering masses, but no one was willing to take it from him. Zerkel, aggravated, threw the wafer onto the floor and trod it into the dirt. Later, a heavenly vision led the baker's son into Zerkel's house, where the remaining third of the maltreated host, still wrapped in the bloodied cloth, suddenly appeared in his hand. Since he considered himself unworthy of holding the body of Christ in his hands, he put the wafer on the threshold which was seen by two women passing by. The news spread quickly and a throng of people gathered at the Jew's house. Soon, they remembered the recent incident-the Jews chasing after the servant - and started to cry out for punishment. The scholar was burnt at the stake immediately, and Zerkel, who had, with the help of some aldermen, been hiding in a house, was beaten to death by the enraged masses. In this rendition that even made it into a collection of folk tales ${ }^{114}$ no doubts were raised about the Jews' guilt and that they received their 'divine retribution.'

The altar is now kept at the Stiftmuseum Klosterneuburg (Museum of the Monastery of Klosterneuburg), where it was brought to after the dissolution of the Korneuburg monastery in 1808. Stelzer, "Am Beispiel Korneuburg," 317-19, with ill. no. 2 (see note 12).

Albert Starzer, Geschichte der landesfürstlichen Stadt Korneuburg (1899, rpt.; Korneuburg: Museumsverein, 1991); Franz Zeissl, Geschichte der Stadt Korneuburg, vol. 1 (Vienna: TouristikVerlag, 1959), 73-74, and idem, Das ehemalige Augustinerkloster in Korneuburg, 3-7 and 28-30 (see note 33).

Stelzer, "Am Beispiel Korneuburg," 316, who also points out that since Starzer quotes Pope Benedict's letter, he must have known about the manufactured evidence, yet chose to give this completely uncritical and clearly biased rendition (see note 12). 
What can we conclude about the fourteenth-century citizens of Korneuburg? The contradictions that appear in the record of the interrogations, the accusation by the priest, and the statement 'I did not see it' of the witnesses notwithstanding, the contemporaries of the early fourteenth century, be they rural, urban, or courtly, genuinely believed in the Jews' collective guilt. Yet was this belief unanimous? There seems to have been doubt among some of the theologically trained, although their concern rested more with the question of the genuineness of the host and its miracles. But there was also room for doubt among the Jews' neighbors, those with whom they had lived side by side rather peacefully until then. Disagreements occured during the interrogation: the citizens shifted the blame onto the scholar by claiming that he had named Zerkel as the sole culprit. The suggestion that the scholar might have been innocent hangs in the air, yet is heavily qualified by Otto an dem Roßmarkt who reports that even the scholar himself had conceded that they, the Jews, had met their destiny. ${ }^{115}$ Nevertheless, the citizens seemed to have been quite hesitant to state that they firmly believed in the Jews' guilt. None of the interviewees admitted to having actively participated in the killing of the Jews; and we may question whether they said what the authorities wanted to hear, whether they were afraid of admitting to the killings, or whether at least some of them actually harbored doubts about the Jews' guilt.

Konrad Reus's wife testified at the interrogation that she had been present when the host wafer had been found, yet she did not mention (and was not asked) anything about Zerkel being at their home. Had the two Christians, the two Marquards, who had ushered Zerkel into Konrad Reus's house, the moment their neighbors returned (and perhaps told them about the Jewish scholar's last words, and his unmarred head), continued to guard Zerkel, or had they reached for a cudgel and joined the murderous mob? We do not know. The phrasing of the testimony of Heinrich Shem, the witness who tells us about the two Marquards who had tried to hide Zerkel, suggests that Zerkel had indeed hoped to find protection there, and that the mob had entered the house by force. Heinrich too claims not to have partaken in Zerkel's killing, yet we can't be sure, of course. What we do know is that blood had indeed been spilt, and it had been the blood of the Jews.

This is the comment by Otto an dem Rossmarkt (eighth witness), who also claims that Heinrich von Etzleinsdorf, Heinrich's brother, and Konrad an der Hochstrass were present during the scholar's alleged confession (Brugger and Wiedl, Regesten 1, 134, no. 133 [see note 1]). 


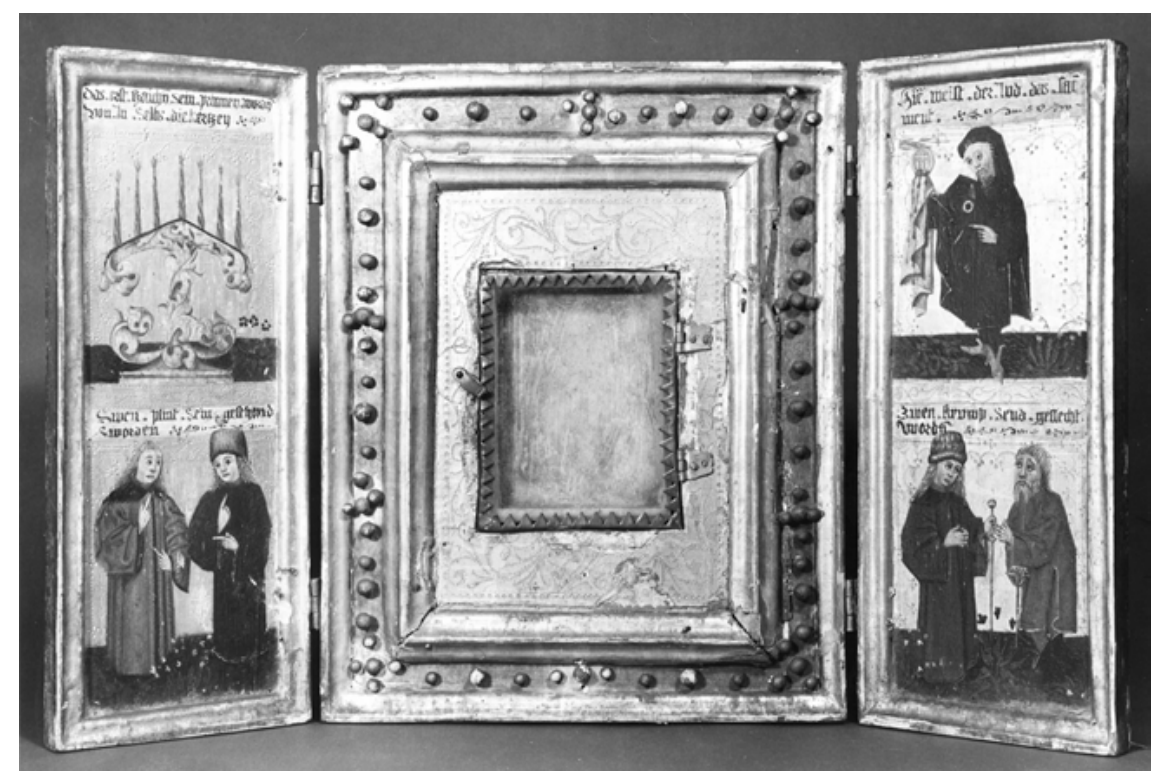

Fig. 1: Stiftsmuseum Klosterneuburg, Inge Kitlitschka, Klosterneuburg. Portable altar (around 1470) with four paintings (upper left: spontaneous ignition of candles, upper right: the Jew holding the host, bottom left: two blind regain their sight, bottom right: two crippled are cured) 


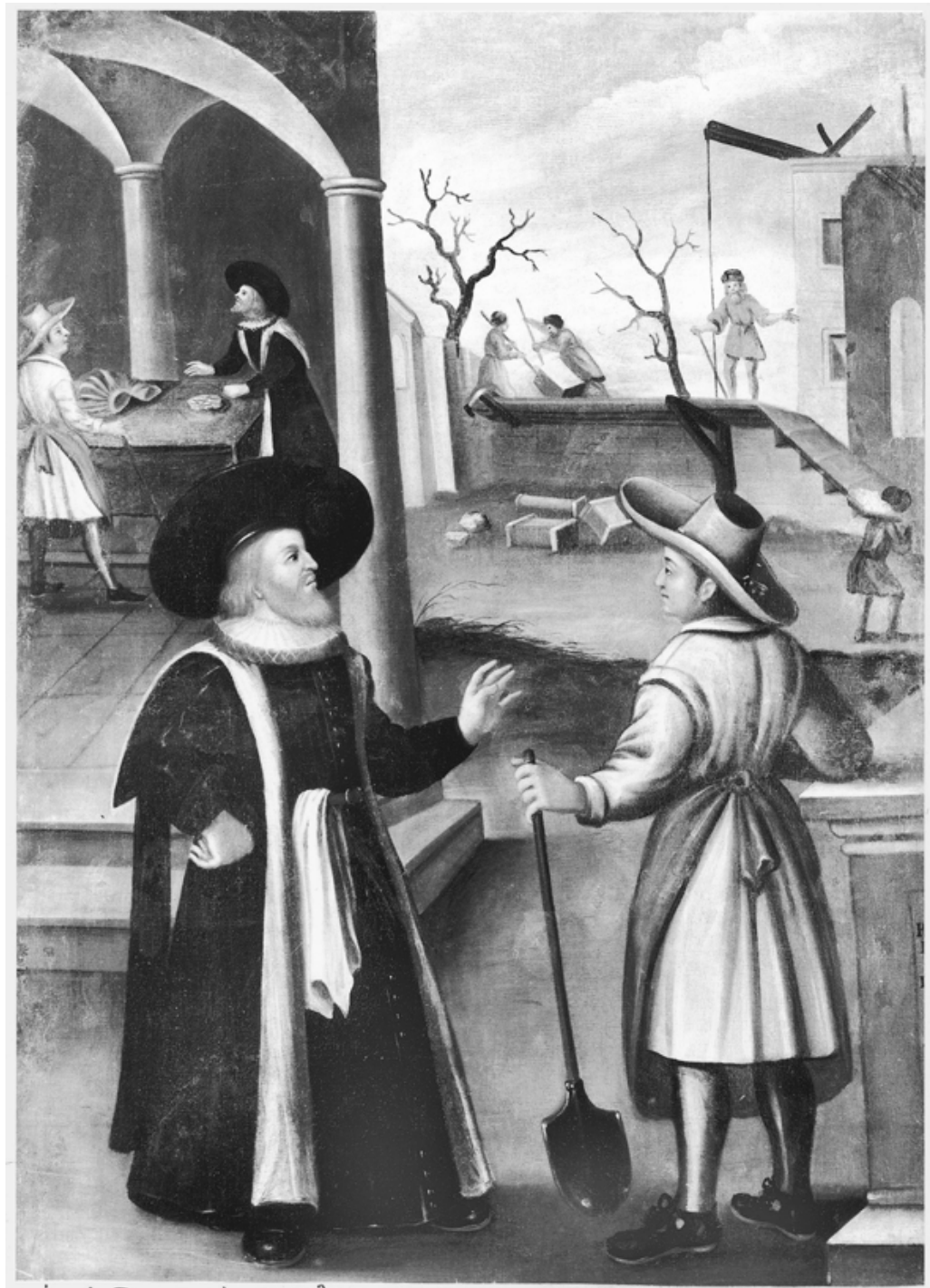

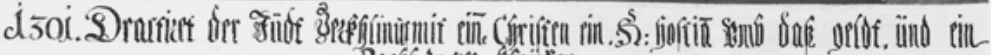

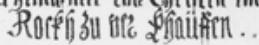

Figs. 2 - 12: Stadtmuseum Korneuburg. Cycle of paintings, oil, 1660, eleven of the originally twelve paintings that were on display in the cloister of the monastery of Korneuburg, now kept at the Municipal Museum

Fig. 2: "1301, the Jew Zerklin made a Christian sell a holy host wafer for money and a coat." Background, left: Zerkel offers a red coat and money to the Christian. [No donation] 


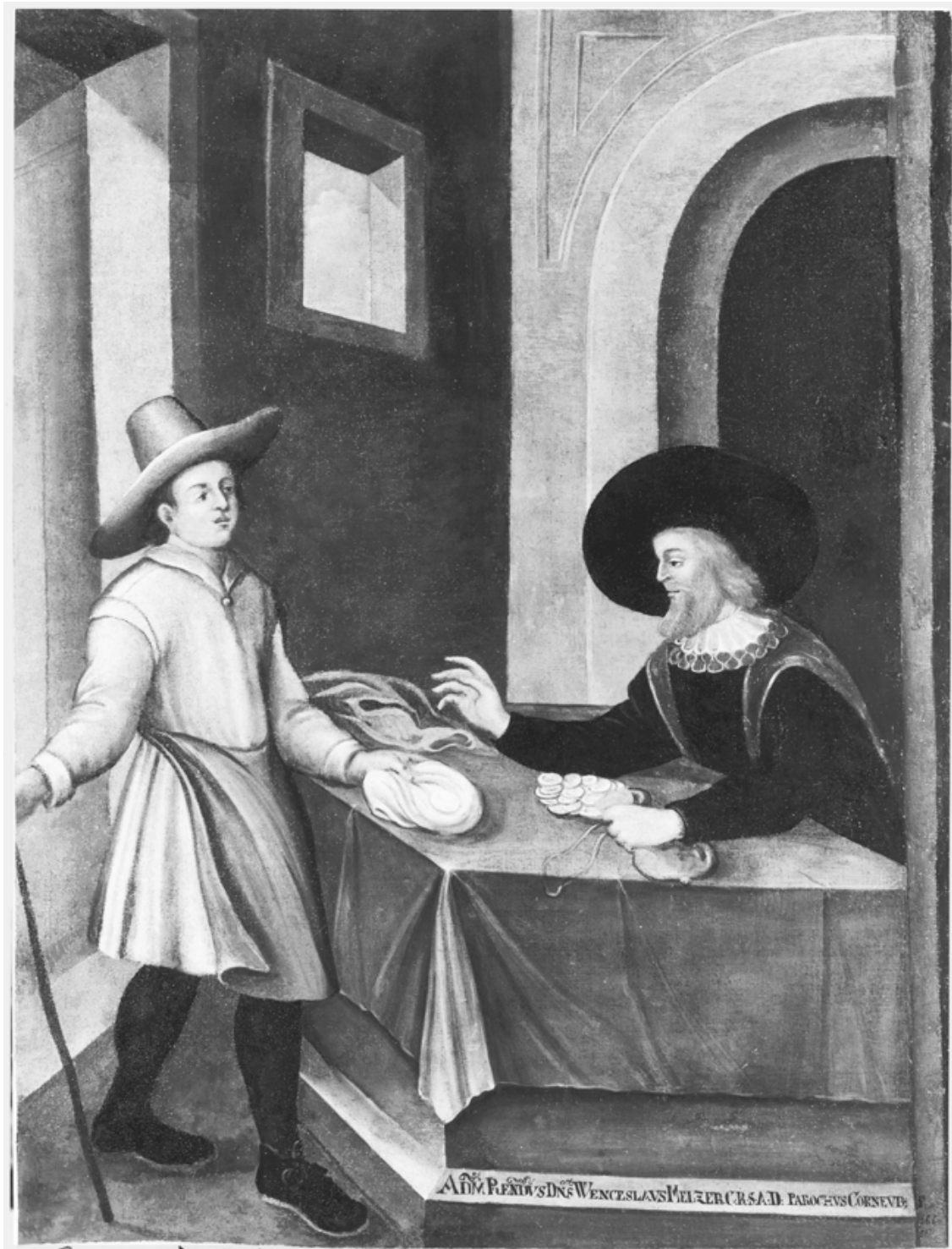

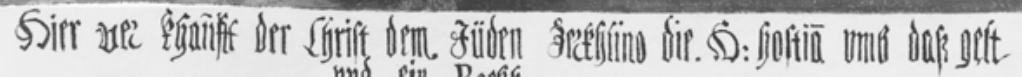
ant sillm Rotefín

Fig. 3: "Here, the Christian sells the host to Zerkel the Jew for money and a coat." Donated by Wenzeslaus Melzer, CRSA [= Canon Regular], parish priest of Korneuburg 


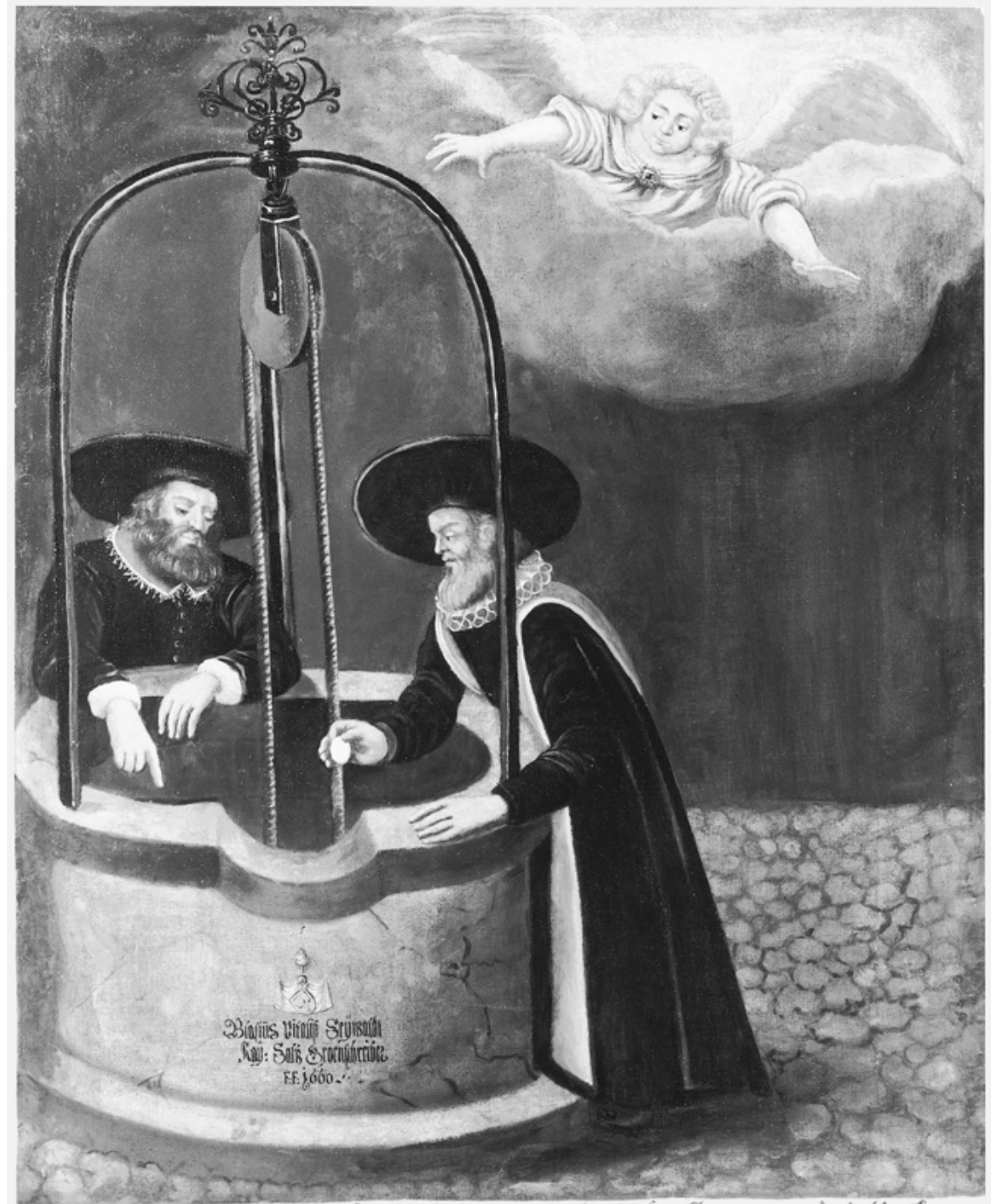

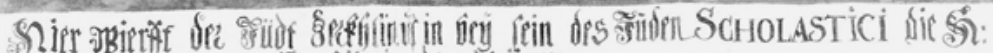

5 Sovition, ill dem teimen.

Fig. 4: "Here, the Jew Zerkel throws the host into the well in the presence of the Jew Scholasticus." Donated by Blasius Vitalis Seywald, imperial Salzgegenschreiber (official at the imperial salt authority) 


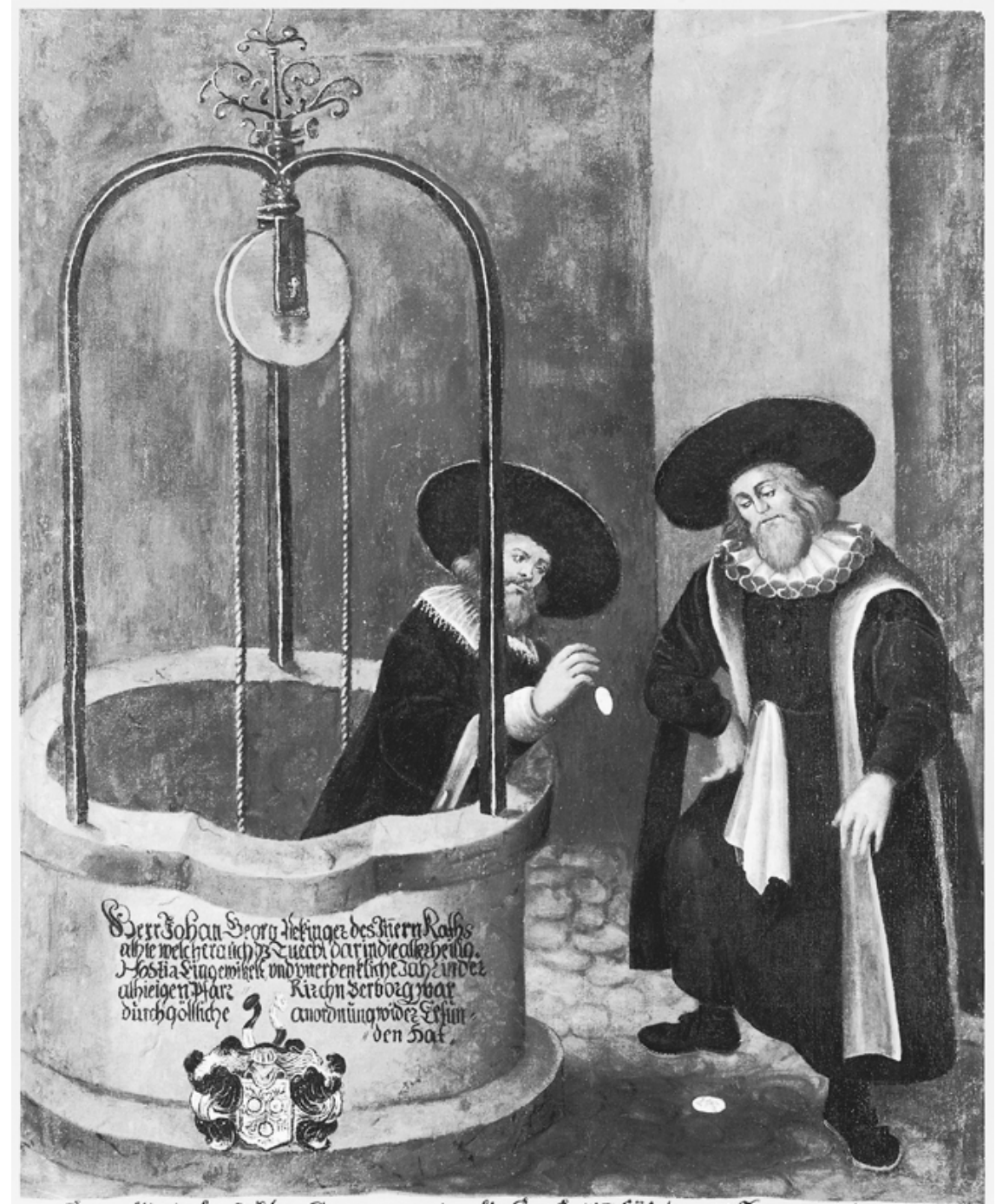

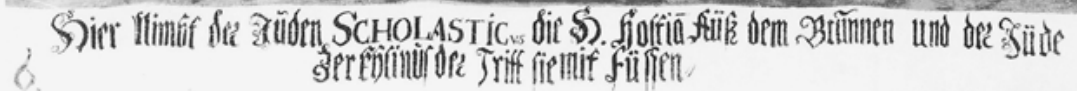

Fig. 5: "Here, the Jew Scholasticus retrieves the host from the well, and the Jew Zerkel trods on it." On the base of the well: "Johann Georg Rekinger, member of the local inner council who recovered the cloth which the most holy host had been wrapped in and which had been hidden in the local parish church for innumerable years, through divine direction." 


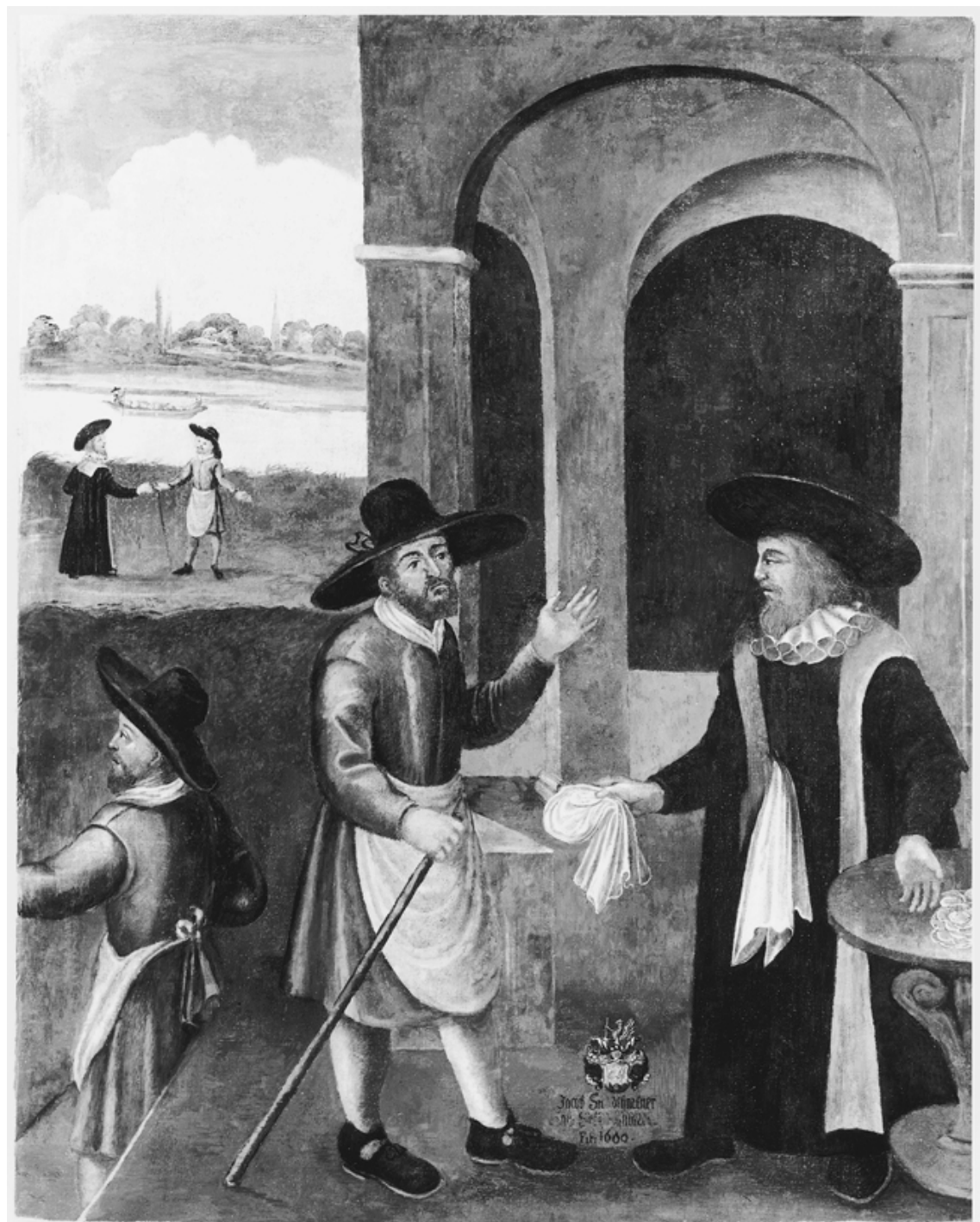

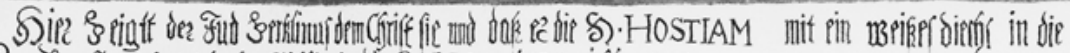

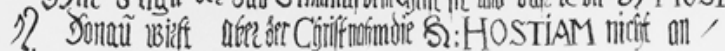

Fig. 6: "Here, the Jew Zerkel shows it [= the host] to a Christian so that he should throw the host together with a white cloth into the Danube, but the Christian did not take the host." Donated by [inscription faded] Jacob Sn[. . . ]hackner [...] 


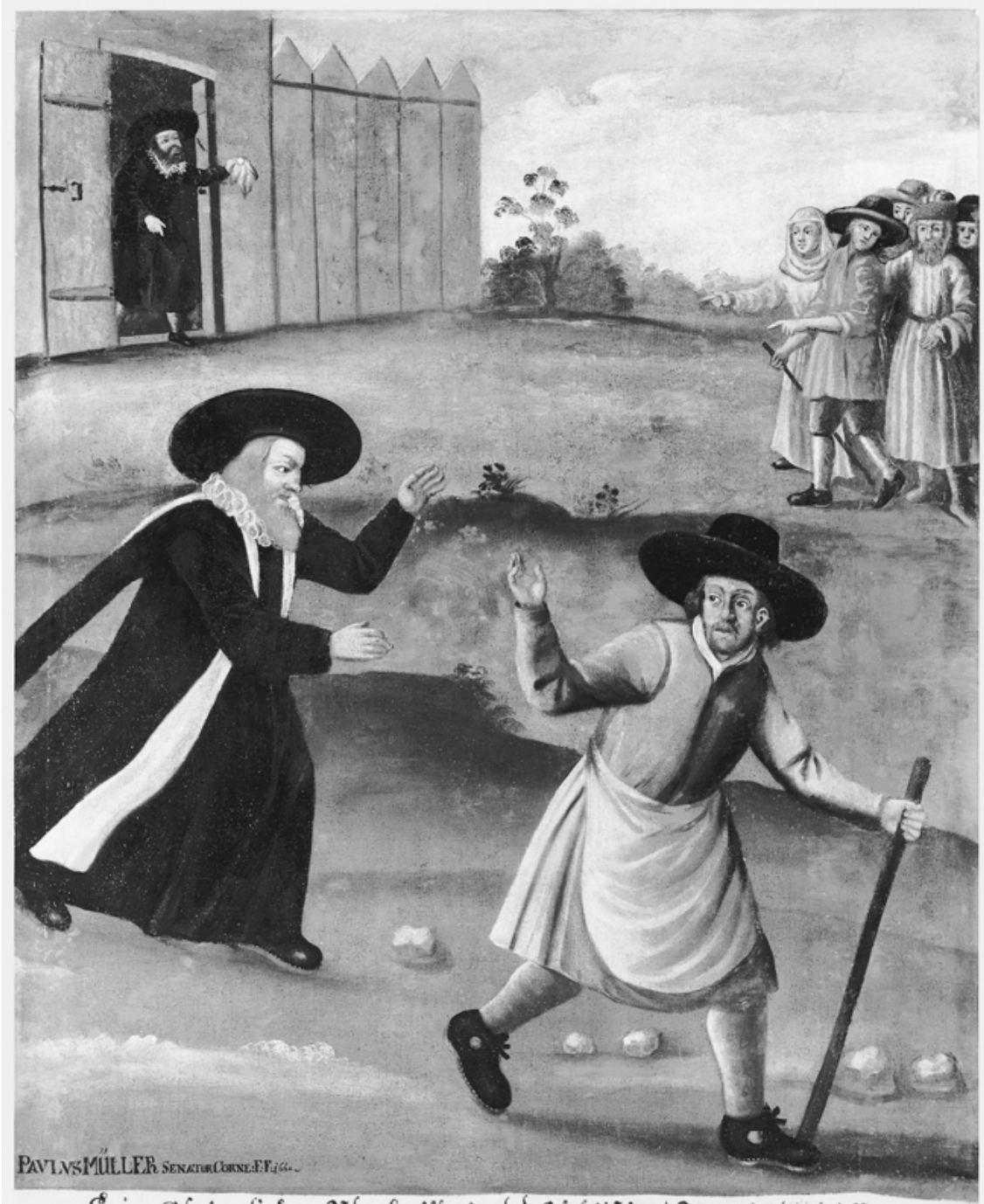

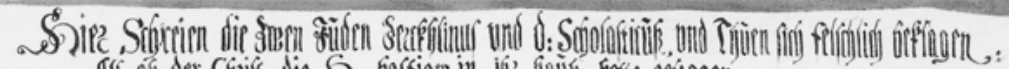

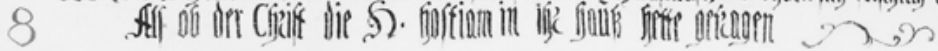

Fig. 7: "Here, the two Jews Zerkel and the Scholasticus cry and falsely complain, as if the Christian had carried the host into their house." Background: One of the Jews appears on the threshold with the host wrapped in cloth. Donated by Paulus Müller, senator of Korneuburg 


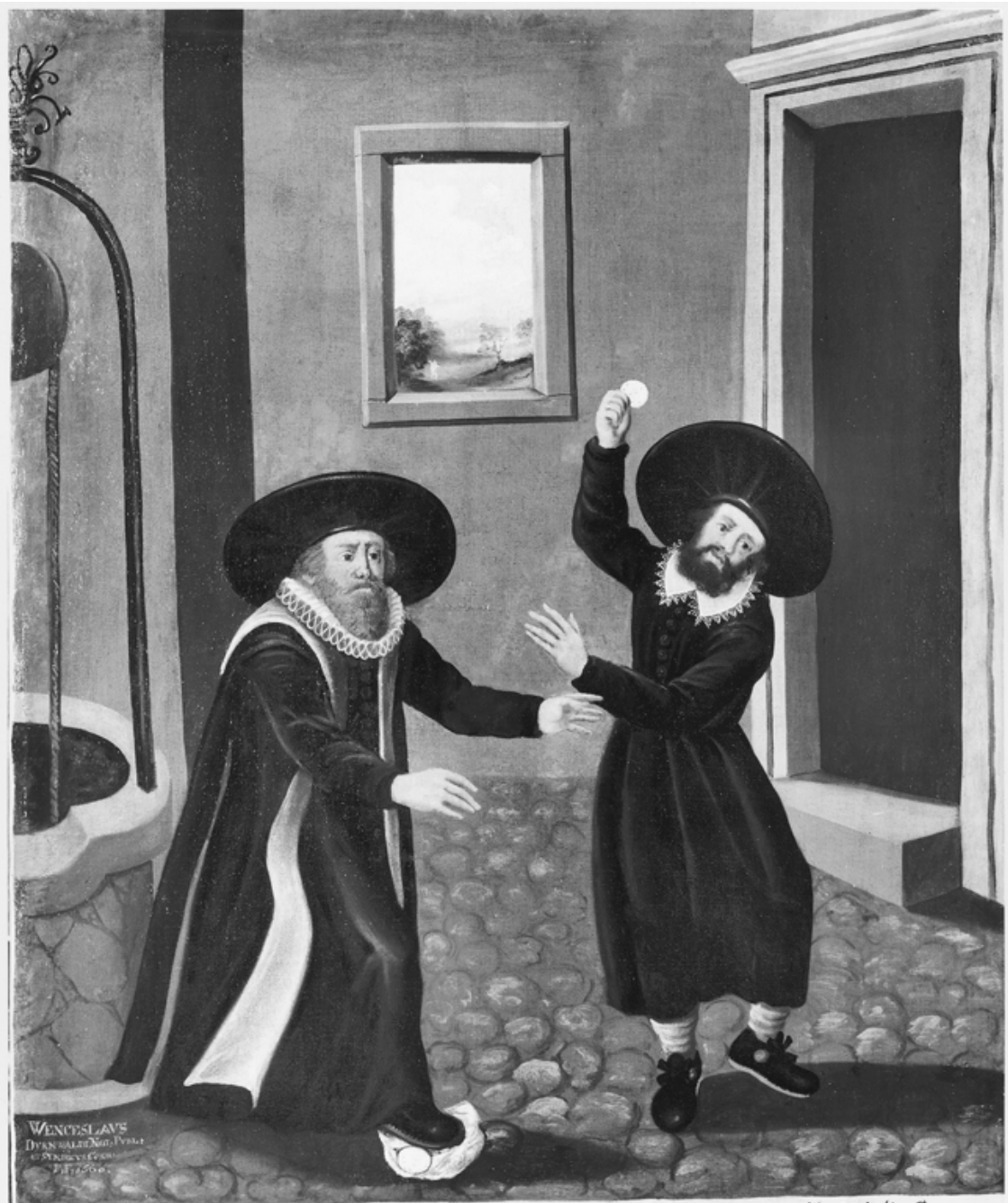

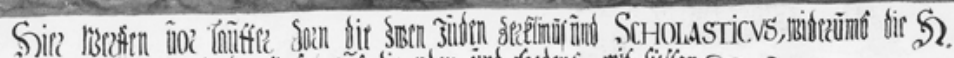

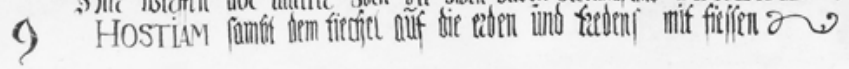

Fig. 8: "Here, the two Jews Zerkel and Scholasticus again throw the host and the cloth to the floor and tread on it in anger." Donated by Wenzislaus Dyrnwald, notary public and syndic at Korneuburg 


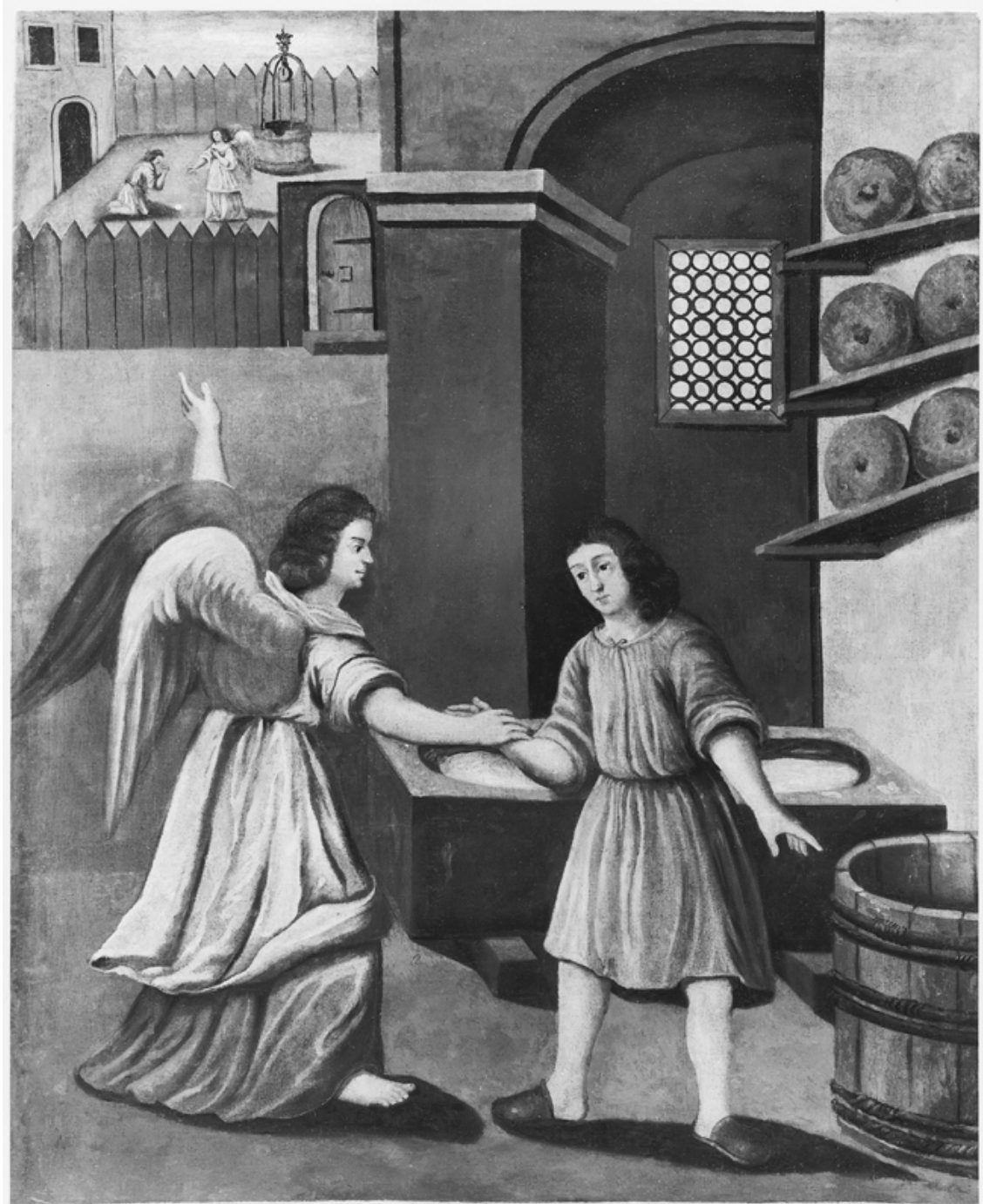

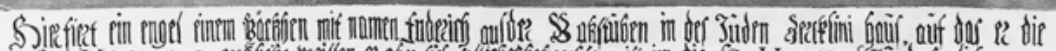
10

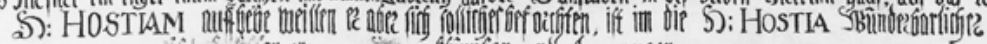

Fig. 9: "Here, an angel guides a backer called Luderich [!] from the bakery to the Jew Zerkel's house so that he should pick up the host; but as he was scared, the host miraculously appeared between his fingers [barely readable]." Background: The baker stoops down to pick up the host. [No donation] 


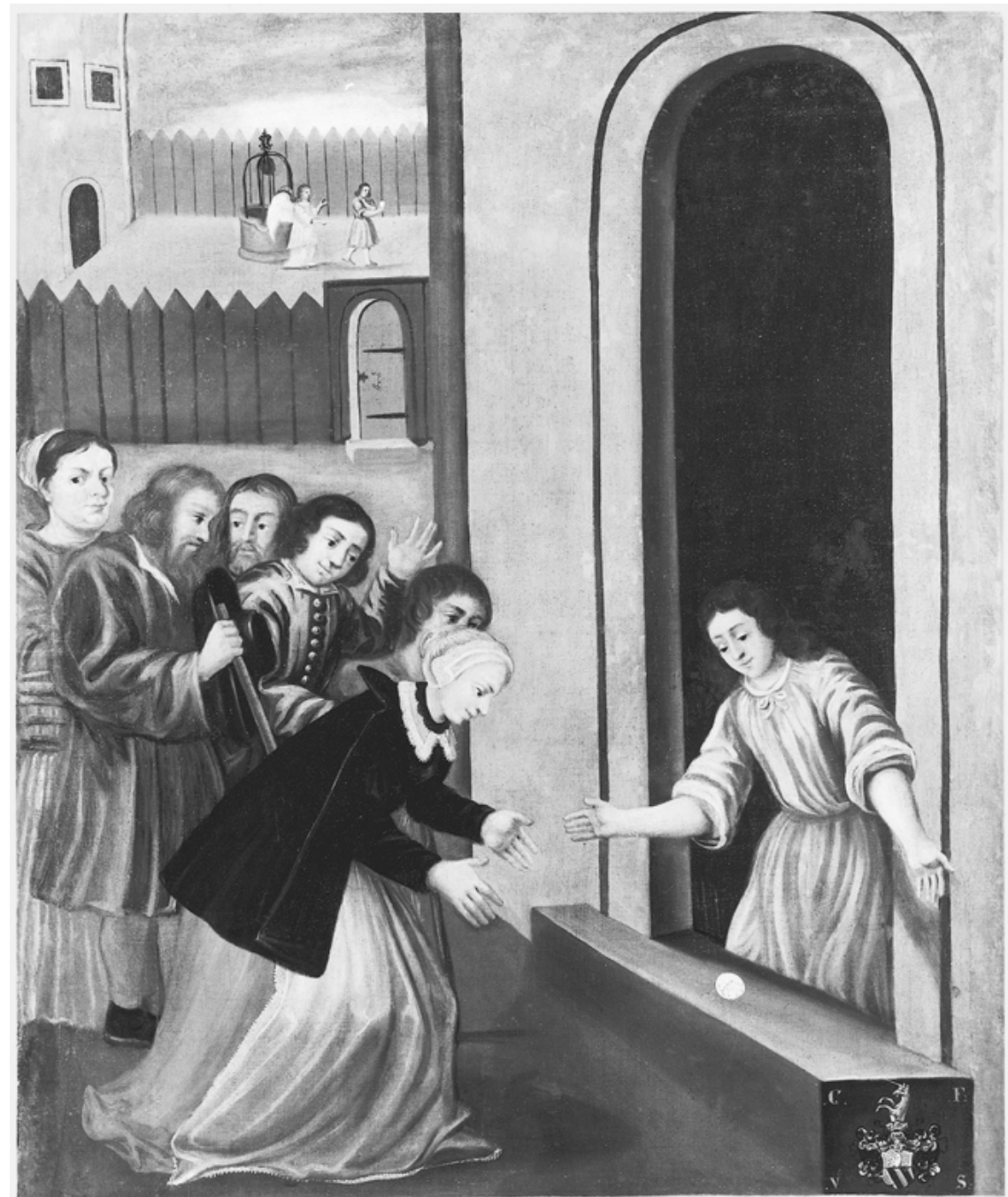

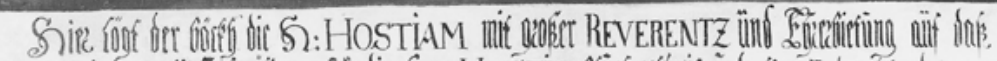

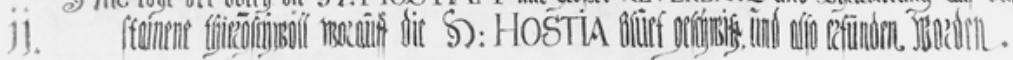

Fig. 10: "Here, the baker puts the host with utmost reverence and obeisance on the stony doorstep, whereupon the host sweated blood and was thusly found."

Background: Led by the angel, the baker carries the host.

Donation: coat of arms and initials CFVS (according to Zeissl, Das ehemalige Augustinerkloster, 30 [see note 33], the coat of arms points at the family of Dachsenbeck) 


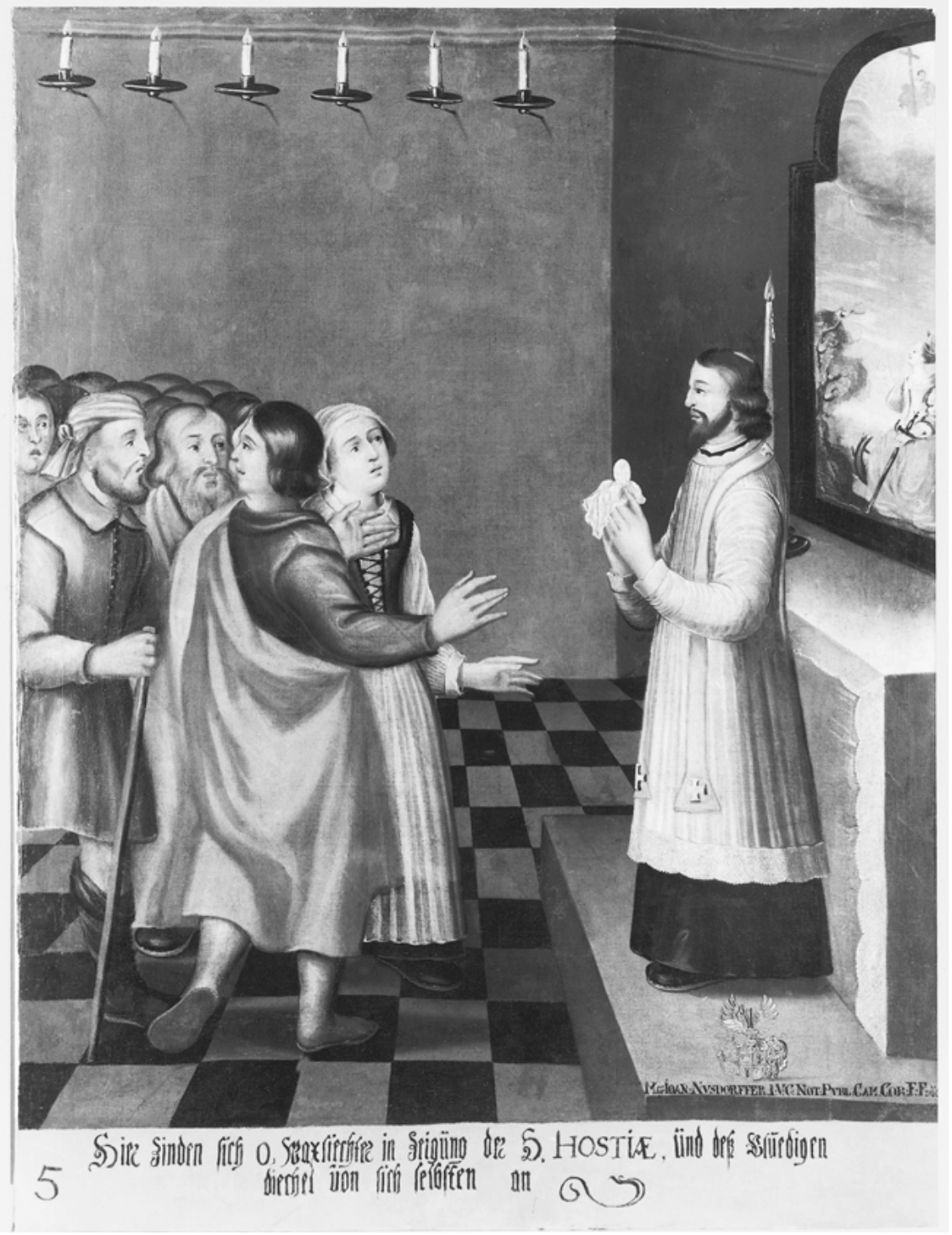

Fig. 11: "Here, 6 (?) wax candles ignite upon being shown the host and the blood-stained cloth." Donated by Johann Nußdorfer, notary public at Korneuburg 


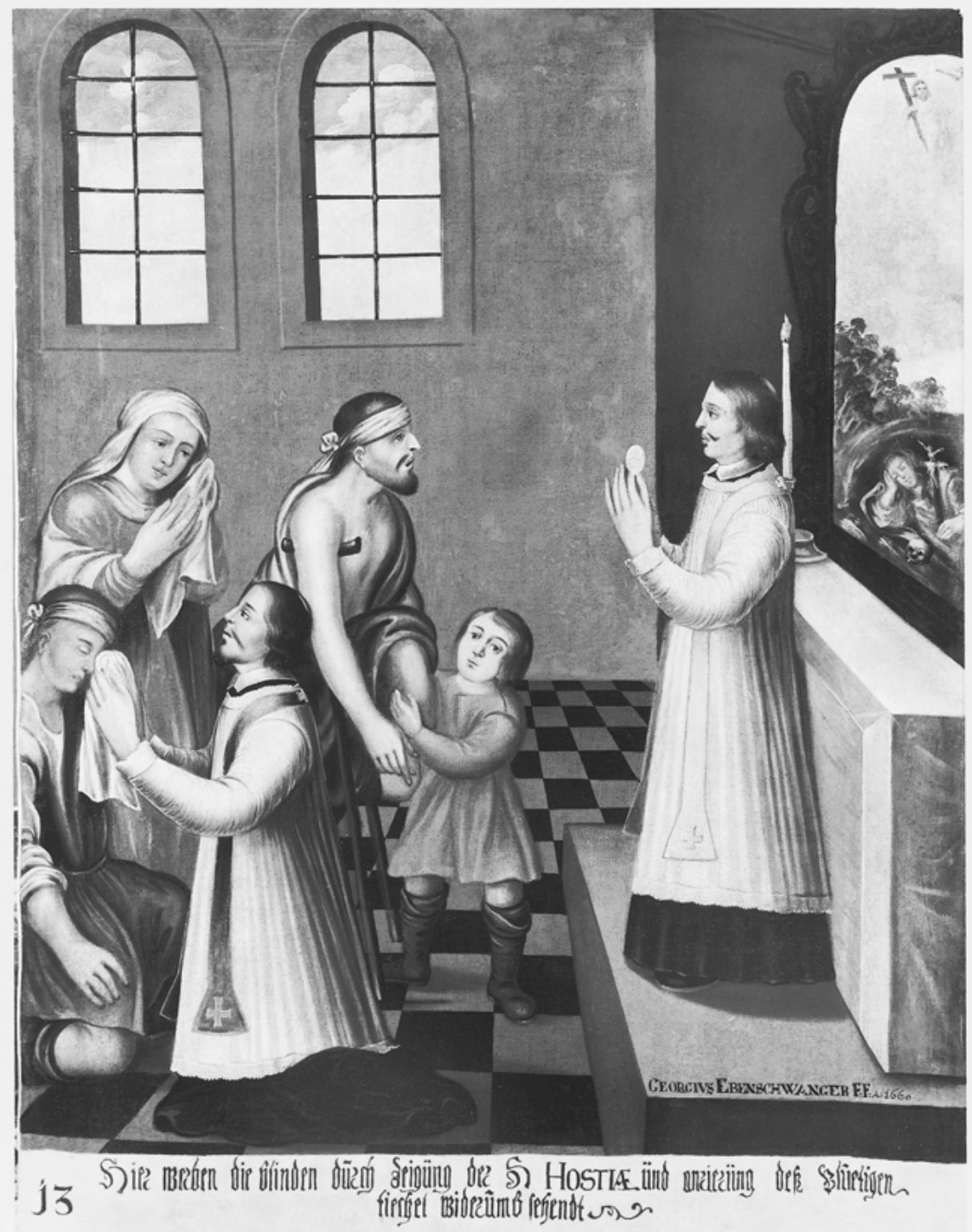

Fig. 12: "Here, the blind are healed by being shown the host and by application of the cloth." [The bearded man appears to be handicapped.] Donated by Georgius Eberschwanger 